\title{
Illustrated keys for the identification of the Pleocyemata (Crustacea: Decapoda) zoeal stages, from the coastal region of south-western Europe
}

\author{
Antonina dos Santos ${ }^{\ddagger}$ and Juan Ignacio González-Gordillo ${ }^{\dagger}$ \\ *Instituto de Investigação das Pescas e do Mar, Avenida de Brasilia s/n, 1449-006 Lisbon, Portugal. ${ }^{\dagger}$ Centro Andaluz de Ciencia y \\ Tecnología Marinas, Universidad de Cádiz, Campus de Puerto Real, 11510—Puerto Real (Cádiz), Spain. ${ }^{\ddagger}$ Corresponding author, \\ e-mail: antonina@ipimar.pt
}

The identification keys of the zoeal stages of Pleocyemata decapod larvae from the coastal region of south-western Europe, based on both new and previously published descriptions and illustrations, are provided. The keys cover 127 taxa, most of them identified to genus and species level. These keys were mainly constructed upon external morphological characters, which are easy to observe under a stereomicroscope. Moreover, the presentation of detailed figures allows a non-specialist to make identifications more easily.

\section{INTRODUCTION}

Identification of decapod larvae from plankton samples is not easy, principally because there are great morphological changes between developmental phases, although less pronounced between larval stages. Moreover, larval descriptions of many species are still unsuitable or even non-existent. Many researchers studying ecological, physiological or other aspects of decapod larvae are not taxonomy experts and they have great difficulty in recognizing a priori the family or the larval stage of one specimen in a plankton sample. Thus, a key is needed to allow identification to start at a higher level, where all decapod larval forms are placed together. Despite the requirement of accurate larval identification and information to conduct studies on this significant crustacean group, comprehensive keys are not available for many regions, and most information is restricted to individual species groups. Since Williamson (1957) prepared a key for all decapods from $40^{\circ} \mathrm{N}$ to $80^{\circ} \mathrm{N}$ in western European waters, no further keys have been published covering other European regions. The southern limit of Williamson's key extends only to the northern coast of Portugal, thus many species from the south-west European coast, and Mediterranean Sea were not included. These latter areas coincide with a region where the identification of decapod larvae is particularly difficult due to the high species diversity found off North Africa, species for which larval descriptions are not available. These limitations, in addition to the high number of larval descriptions published in the last decade, put the current keys somewhat out of date. Recently, identification keys have been made for larvae from the North Atlantic coast (Ingle, 1992; Paula 1996) and the Mediterranean Sea (Pessani et al., 1998), however, only brachyuran larvae. The present key will be a useful tool for identifying plankton, mainly in ecological and life history studies. Moreover, taking into account the lack of keys for areas such as the north-west African coast, Canary Islands, etc. it can be useful for plankton studies in nearby areas as a complement document when identifying larval stages.

The order Decapoda comprises two suborders, the Dendrobranchiata and the Pleocyemata (Martin \& Davis, 2001). A key for the identification of Dendrobranchiata larvae covering the same area of this study has been presented by dos Santos \& Lindley (2001). The present keys for Pleocyemata larvae include the infraorders Stenopodidea, Caridea, Astacidea, Thalassinidea, Palinura, Anomura and Brachyura. With the previous work on the Dendrobranchiata, the keys for the identification of zoeal stages for all the decapod larvae from the south-western European coastal region are completed.

This paper starts with a general key for the identification of larvae infraorders within the Pleocyemata group, organized according to the actual classification sequence (Martin \& Davis, 2001), followed by specific genus and species keys for each infraorder. In the second part of the present work a guide for the identification of the instars is provided. This comprises a list of characters which taken into account together can provide a better distinction among larval stages.

\section{MATERIALS AND METHODS}

The present keys are based on observations made on decapod zoeae from plankton samples collected from the Portuguese and southern Spanish coasts, from other unpublished data from our own larval reference collection, and from published larval descriptions. The new or unrecognized decapod larvae found in the plankton samples were assigned a code number. The characters used to construct the key are generally external morphological ones and easy to observe under a stereomicroscope, while illustrations of specific or subjective features are included to facilitate identification by non-specialists. Larval terminology established by Williamson (1957, 1969). 


\section{GENERAL KEY}

(Figures $1 \& 2$ )

1. (a) Carapace laterally flattened (Figure $1 \mathrm{E}-\mathrm{I}) \ldots .2$

(b) Carapace strongly dorso-ventrally flattened (Figure 1D). . . . . . . Infraorder PALINURA (part) (Key 5)

(c) Carapace almost spherical (Figure $1 \mathrm{~A}-\mathrm{C}$ ) . . . 8 8

2. (a) Telson with two cylindrical rami or terminating in two sharp prongs; antennal exopod segmented throughout its length (Figure $1 \mathrm{G}) \ldots \ldots \ldots \ldots$ ............ Suborder DENDROBRANCHIATA (see dos Santos \& Lindley, 2001)

(b) Telson flattened (Figure 2A-F, H,I); antennal exopod unsegmented or segmented near distal end only ................... 3

3. (a) Second telson spine not 'hair-like', telson usually with seven (zoea I) or eight setae (later zoeas) each half margin (Figure $2 \mathrm{C}, \mathrm{D}) \ldots \ldots \ldots \ldots$

(b) Second telson spine represented by a fine seta, telson usually with seven (zoea I) or eight setae (later zoeas) each half margin (Figure 2A, E, F, H, I) . . . . 6

4. (a) Telson posterior margin without median spine (Figure 2D) .................. 5

(b) Telson posterior margin with median spine (Figure 2G) . . . . . . . . . Infraorder ASTACIDEA (Key 3)

5. (a) First abdominal somite with small dorsal spines; third abdominal somite with long median dorsal spine; fifth abdominal somite with ventral hook shaped spine (Figure 2G) . . . . Infraorder STENOPODIDEA (Key 1) (b) Abdominal somites without these characters . . . . . . . . . . . . . . . . Infraorder GARIDEA (Key 2)

6. (a) Each posterolateral margin of carapace extended into a spinous process (Figure $1 \mathrm{E}, \mathrm{I}) \ldots \ldots \ldots \ldots$ ........... Infraorder ANOMURA (part) (Key 6) (b) Each posterolateral margin of carapace rounded (Figure $1 \mathrm{H}) \ldots \ldots \ldots \ldots \ldots \ldots \ldots \ldots \ldots \ldots \ldots \ldots \ldots$

7. (a) Telson posterior margin with median spine (Figure $2 \mathrm{~F}, \mathrm{H}$ ); when median spine absent, telson margin slightly convex without U-shaped central invagination (Figure 2E) and sharp rostrum present or with antennae and eyes separated from mouthparts ..... . . . . . . . . . . Infraorder THALASSINIDEA (Key 4) (b) Telson posterior margin without median spine and clearly concave; when not concave, telson has U-shaped central invagination (Figure 2A, I) and large rostrum present ....... Infraorder ANOMURA (part) (Key 6)

8. (a) Carapace globose with more than 20 spines (Figure 1C) . . . . . . . . . . Family Polychelidae (b) Carapace usually globose with not more than 20 spines (Figure 1A,B) . Infraorder BRACHYURA (Key 7)

\section{KEY 1-Infraorder STENOPODIDEA}

(Figure 2G)

1. (a) Pleural spines on first and third somites longer than height of abdomen; dorsal spine on third somite longer than pleural spine (Figure $2 \mathrm{G}$ ). . . . . Stenopus spinosus

(b) Without this combination of characters . . . . . . .

Other species

1. (a) Sessile eyes (Figures 3B, E, N; 4A, B, E, H).... . . . . . . . (Zoea I; except for Athanas nitescens) 2 (b) Movable eyes (Figures 3G-I, K; 4C, F, G, I, J) 29

2. (a) Antennal scale not segmented (Figure 4A) . . . 3 (b) Antennal scale segmented (Figures 3B; 4B, E, $\mathrm{K} ; 5 \mathrm{E}, \mathrm{L}) \ldots \ldots \ldots \ldots \ldots$

3. (a) Pleopod buds present (Figure 3A, F, N) ..... 4 (b) Without pleopod buds . . . . . . . . 7

4. (a) Eyes small (Figure 3F, N). . . . . . . . . 5 (b) Eyes well developed (Figure 3A) . . . . . 6

5. (a) Eyes unpigmented; telson very broad and round apically . . . . . . . . . . Genus Parapasiphaea (b) Eyes pigmented; telson not very broad with $7+7$ setae; carapace full of red yolk (Figure $3 \mathrm{~N}$ ) . . . . . . $\ldots \ldots \ldots \ldots \ldots \ldots$. . . . . . . . . .

6. (a) Telson with $10+10$ setae ...... Pasiphaea sivado (b) Telson with $18+18$ setae . . Pasiphaea multidentata

7. (a) Fifth pereiopod well developed (Figure 5Q) ..

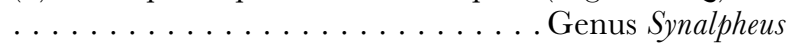
(b) Without fifth pereiopod ........... 8

8. (a) Telson with deep central invagination (Figure 3C) . . . . . . . . . . . Genus Pontophilus (b) Telson without the above character . . . . . . . 9

9. (a) Antennule exopod placed subterminally on peduncle; third abdominal somite with a prominent median dorsal spine (Figure 3I) . . . . . Genus Aegaeon (b) Antennule exopod placed terminally on peduncle (Figures 4B, K; 5O) . . . . . . . . . . . 10

10. (a) Bases of antennules separated by more than width of one of them (Figure 4A) . . . . . . Genus Processa (b) Bases of antennules close or separated by not more than width of one of them (Figure $4 \mathrm{H}) \ldots \ldots \ldots 11$

11. (a) Third abdominal somite with a median dorsal spine; fifth abdominal somite with a pair of spines (Figure $5 \mathrm{~K}$ ) ............. Crangon crangon (b) Third abdominal somite without median dorsal spine $($ Figure $5 \mathrm{~L}) \ldots \ldots \ldots \ldots \ldots \ldots$ 


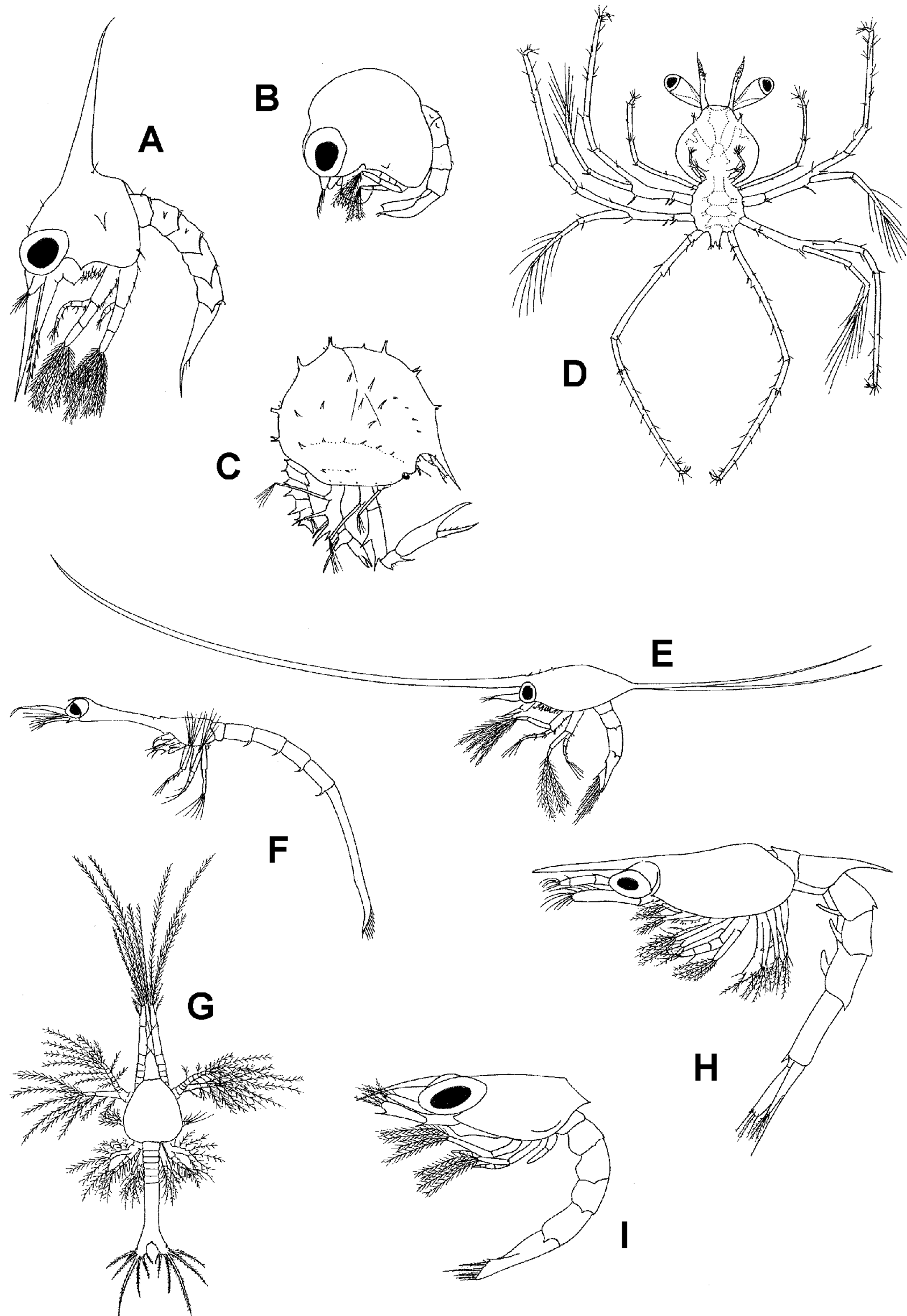

Figure 1. Aspects of whole decapod larvae. (A) Zoea II of Xantho poressa; (B) zoea II of Ebalia tuberosa; (C) indeterminate zoeal stage of Polychelidae; (D) zoea I of Scyllarus posteli; (E) zoea I of Porcellana platycheles; (F) zoea II of Faxea nocturna; (G) protozoea I of Sicyonia carinata; (H) zoea V of Callianassa subterranea; (I) zoea I of Catapaguroides timidus. (A, redrawn from Rodríguez \& Martin, 1997; B, from Salman, 1982; C, from Selbie, 1914; D, from González-Gordillo \& Rodríguez, 2000; E, from González-Gordillo et al., 1996; F, H, from Gurney, 1942; G, from Heldt, 1938; I, from Pike \& Williamson, 1960). 

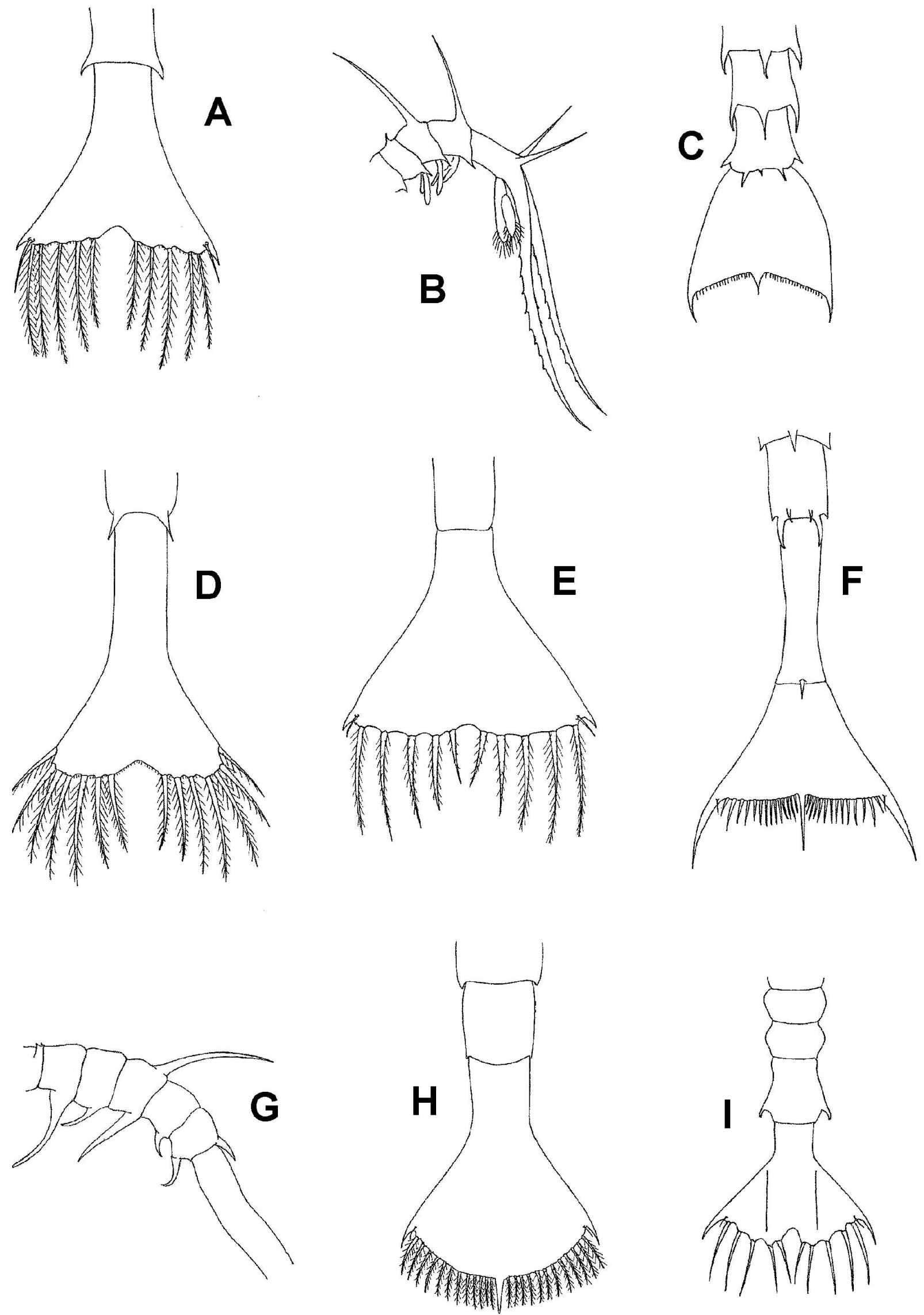

Figure 2. Telsons and abdomens of some decapod larvae. (A) Zoea I of Diogenes pugilator; (B) zoea III of Nephrops norvegicus; (C) zoea I of Homarus gammarus; (D) zoea I of Philocheras monacanthus; (E) zoea I of Upogebia sp.; (F) zoea II of Axius stirhynchus; (G) zoea I of Stenopus spinosus; (H) zoea I of Callianassa sp.; (I) zoea I of Dardanus arrosor. (B, redrawn from Gurney, 1942; C, from Ingle, 1992; D, from González-Gordillo et al., 2000; I, from Pike \& Williamson, 1960). 

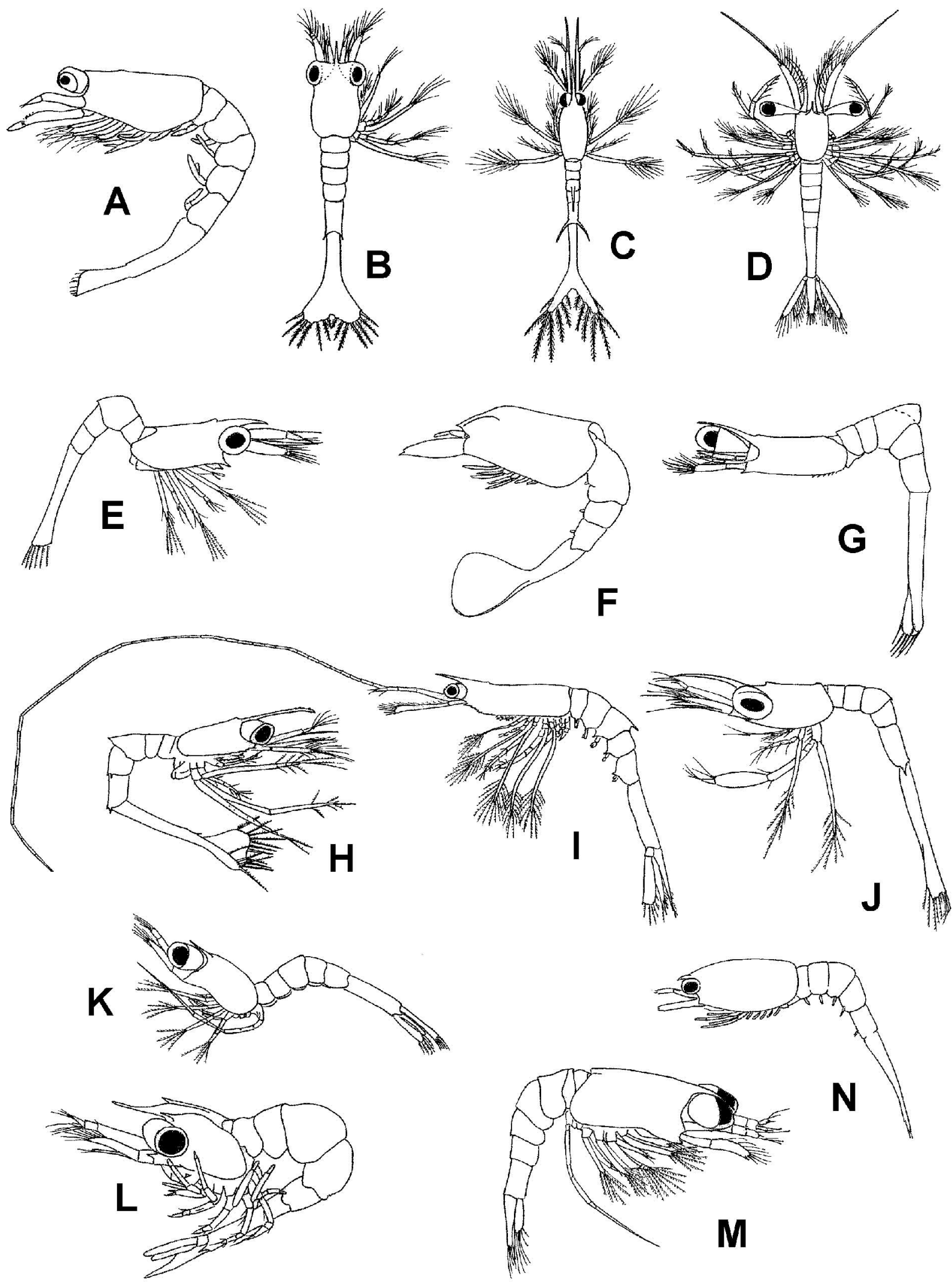

$\mathbf{N}$

Figure 3. General aspects of caridean larvae. (A) Zoea I of Pasiphaea sivado; (B) zoea I of Dichelopandalus bonnieri; (C) zoea I of Pontophylus spinosus; (D) zoea V of Stylopandalus richardi; (E) zoea I of Pontonia pinnophylax; (F) zoea I of Parapasiphaea sulcatifrons; (G) zoea II of Acanthephyra; (H) zoea I of Pandalidae sp. 1; (I) zoea IV (?) of Aegaeon cataphractus; (J) zoea I of Caridion gordoni; (K) zoea III of Athanas nitescens; (L) zoea IV of Pontoninae F8; (M) zoea II of Synalpheus sp.; (N) zoea I of Systellaspis debilis. (A, I (as Pontocaris cataphractus), redrawn from Williamson, 1960; B, D (as Parapandalus richardii), from Lebour, 1940; C, from Sars, 1890; E, from Bourdillon-Casanova, 1960; F, from Kemp, 1910; G, H, K, L, from dos Santos, 1999; J, from Sars, 1900; N (as Acanthephyra debilis), from Kemp, 1910). 
12. (a) Third to fifth abdominal somites with a pair of lateral spines (Figure 5L) . . . . . . Genus Philocheras (b) Only fifth abdominal somite with a pair of strong lateral spines ............. Crangon allmani

13. (a) Abdomen with six somites. . Chlorotocus crassicornis (b) Abdomen with five somites (Figure 3B, E, H) . .14

14. (a) Third abdominal somite with hump (Figure 3G) 15 (b) Third abdominal somite without hump (Figure

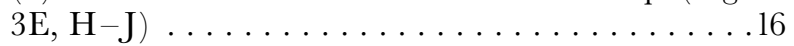

15. (a) Anterior and posterior margins of carapace with denticles (Figure 3G) . . . . . . Genus Acanthephyra (b) Anterior and posterior margins of carapace without denticles . . . . . . . . Genus Nematocarcinus

16. (a) Fifth pereiopod well developed (Figure $3 \mathrm{~K}$ ) . . 17 (b) Fifth pereiopod as bud, when present (Figure

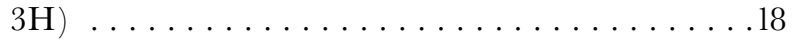

17. (a) Eyes pointed (Figure 4G) .........Alpheus glaber (b) Eyes rounded................ Alpheus spp.

18. (a) Dorsal connection between carapace and abdomen almost make $90^{\circ}$ angle (Figure $3 \mathrm{E}$ ) . . . . . . . ................ Subfamily Pontoniinae (b) Dorsal connection between carapace and abdomen almost make $180^{\circ}$ angle (Figure $3 \mathrm{H}-\mathrm{J}$ ) . . . . . 19

19. (a) Bases of antennules separated by more than width of one of them (Figures 3B; 4A, D,E) . . . . . 20 (b) Bases of antennules close together (Figures 3C; 4B,

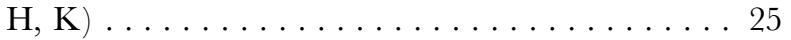

20. (a) Fifth abdominal somite with a pair of lateral spines (Figure 3B, H, J) . . . . . . . . . . . . 22 (b) Fifth abdominal somite without a pair of lateral spines ..........................

21. (a) Rostrum small (Figure 4E) .. Pandalina brevirostris (b) Rostrum long (Figure 4D) . . . . Genus Plesionika

22. (a) Fifth abdominal somite with 1-3 median dorsal spines (Figure $3 \mathrm{H}$ ) . . . . . . . Pandalidae sp. 1 (b) Fifth abdominal somite without median dorsal spines $($ Figure $3 \mathrm{~B}) \ldots \ldots \ldots \ldots . \ldots . \ldots 23$

23. (a) Denticles on the ventral margin of carapace (Figure $5 \mathrm{E}$ ) . . . . . . . . . . . . . . 24 (b) Ventral margin of carapace not denticulate .................... Genus Caridion

24. (a) Antennule with two aesthetascs and two setae; antennal endopod with two spines, the shorter reaching the tip of the scale . . Dichelopandalus bonnieri (b) Antennule with four aesthetascs and one seta; antennal endopod with one long spine and a very short seta (Figure 5M) . . . . . . . . Genus Lysmata

25. (a) Telson enlarged apically without central invagination (Figure 5J) ..............Genus Palaemon (b) Telson not enlarged (Figure 5K, L) . . . . . 26
26. (a) Ventral margin of carapace denticulate (Figure

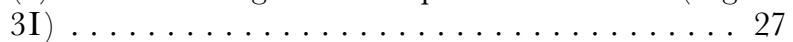
(b) Ventral margin of carapace not denticulate .................. Genus Cinetorhynchus

27. (a) Fifth abdominal somite with a pair of spines (Figure 5I) . . . . . . . . . . . . . 28 (b) Fifth abdominal somite without spines . . . . . . ...................... Genus Eualus

28. (a) Rostrum long (Figure 4B) . . . . Genus Hippolyte (b) Rostrum absent, or when present very small (Figure $4 \mathrm{~K}) \ldots \ldots \ldots \ldots$ Genus Thoralus

29. (a) Dorsal connection between the carapace and the abdomen making a $90^{\circ}$ angle (Figure $3 \mathrm{E}, \mathrm{K}$ ) . . . 30 (b) Third abdominal somite with a hump (Figures

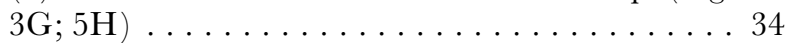
(c) Body-shape without any of the above characters (Figure 3I, M) . . . . . . . . . . . . . . . 35

30. (a) Carapace with supra-orbital spines (Figures 3L;

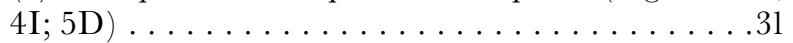
(b) Carapace without supra-orbital spines . . . . . . . . . . . . . . . . . Athanas nitescens

31. (a) Carapace with a median-dorsal carina (Figure

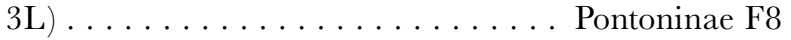
(b) Carapace without a median-dorsal carina (Figure

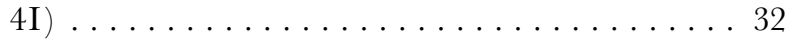

32. (a) Supra-orbital spine short and smooth (Figure

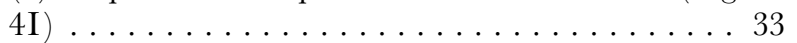
(b) Supra-orbital spine long and serrated (Figure 5D)................... Genus Periclimenes

33. (a) Antennal endopod very long, at least twice the length of the antennal scale (Figure $5 \mathrm{C}$ ) . . . . . . ............. Family Rhynchocinetidae (b) Antennal endopod not reaching or slightly exceeding the distal margin of antennal scale (Figure 5P) . . . . . . . . . . . . Genus Pontonia

34. (a) Fifth abdominal somite with dorso-lateral spines (Figure $5 \mathrm{H}$ ) . . . . . . . . Genus Acanthephyra (b) Fifth abdominal somite without dorso-lateral spines .............. Genus Nematocarcinus

35. (a) Eye-stalk long and slender (Figure $4 \mathrm{~J}) \ldots \ldots \ldots$ . . . . . . . . . . . . . . Genus Lysmata (b) Eye-stalk funnel-shaped (Figure 4G) . . . . . .

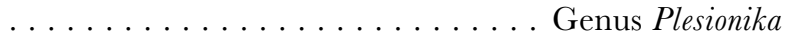
(c) Eye-stalk without the characters described above (Figures $3 \mathrm{M} ; 4 \mathrm{~F}) \ldots \ldots \ldots \ldots \ldots$

36. (a) Fifth pereiopod very long reaching the anterior part of carapace (Figure $3 \mathrm{M}) \ldots \ldots \ldots \ldots \ldots$ (b) When present fifth pereiopod not long, the same size as the others pereiopods . . . . . . . . . 37

37. (a) Fifth pereiopod with exopod (Figure 5R) . . . 38 (b) When present fifth pereiopod without exopod. 39 

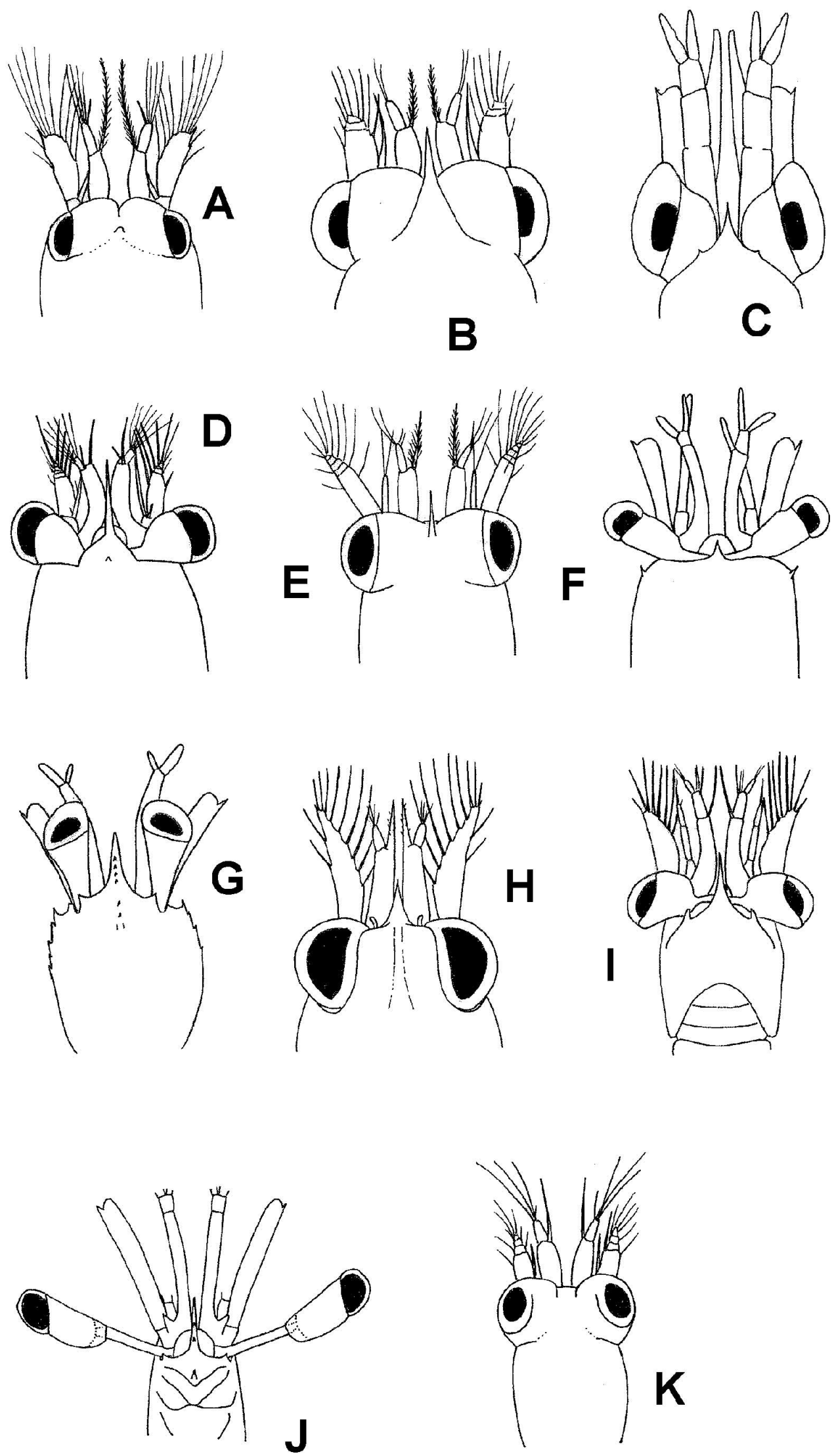

Figure 4. Gephalic appendages of caridean larvae. (A) Zoea I of Processa macrodactyla; (B) zoea I of Hippolyte varians; (C) zoea VI of Alpheus glaber; (D) zoea II of Plesionika FSL12; (E) zoea I of Pandalina brevirostris; (F) zoea V of Processa edulis; (G) zoea V of Plesionika; (H) zoea I of Philocheras monacanthus; (I) zoea III of Pontonia pinnophylax; (J) zoea VIII of Lysmata seticaudata; (K) zoea I of Thoralus cranchi. (A, redrawn from González-Gordillo \& Rodríguez, 2000; B, from Sars, 1911; C, F, G, J, from Paula, 1993; D, from dos Santos, 1999; E, from Gurney, 1942; H, from González-Gordillo et al., 2000; I, from Calafiore et al., 1991; K (as Spirontocaris cranchii), from Lebour, 1932). 

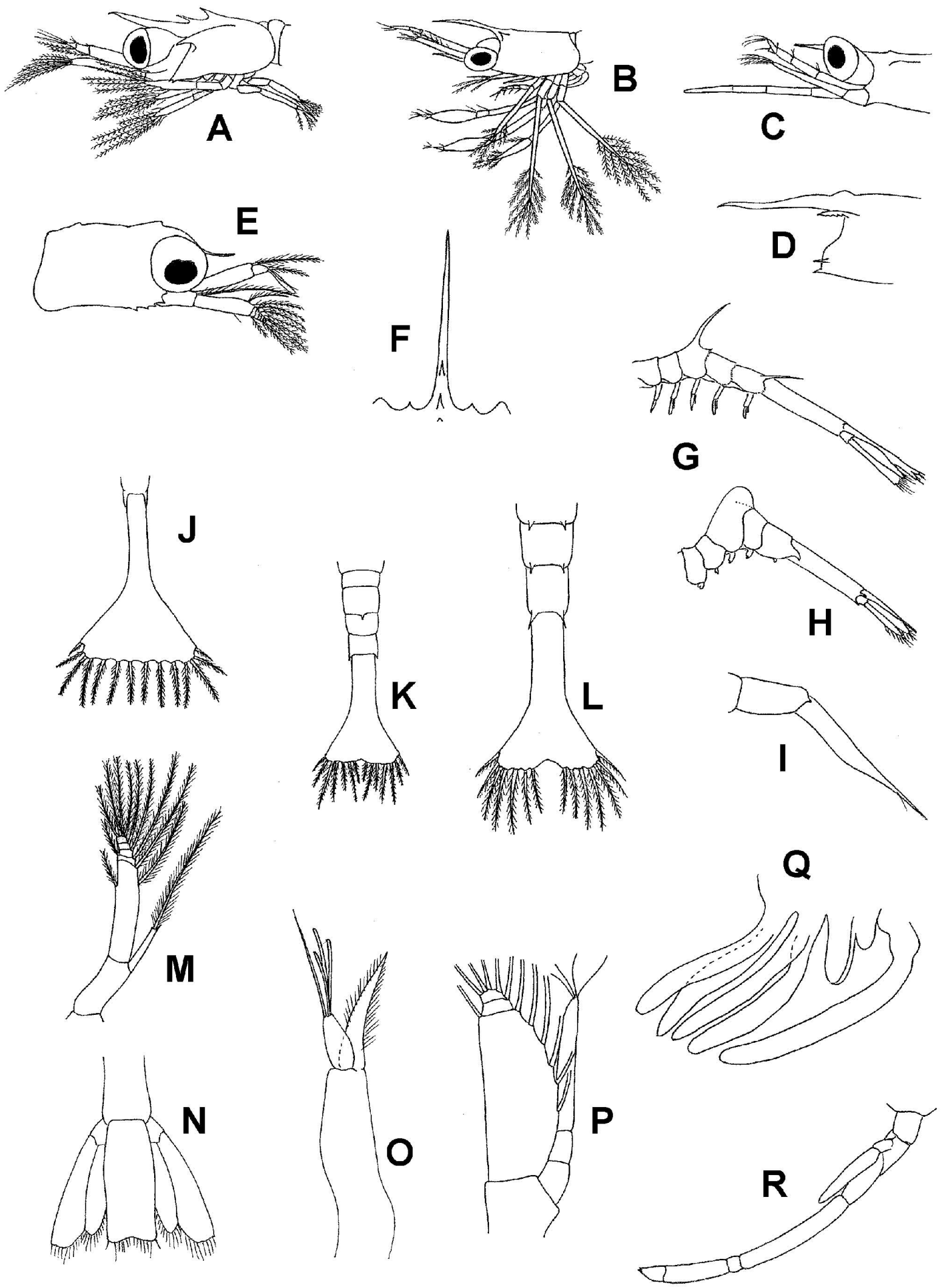

Figure 5. Some appendages of caridean larvae. (A) Zoea III of Palaemon elegans; (B) zoea IV of Caridion gordoni; (C) antero-lateral view of zoea IV of Rhynchocinetes rigens; (D) carapace of zoea IV of Periclimenes sp.; (E) zoea I of Lysmata seticaudata; (F) front of carapace of antipenultimate stage of Stylopandalus richardi; $(\mathrm{G})$ last stage of Pontophilus norvegicus; (H) abdomen of zoea VIII (?) of Acanthephyra purpurea; (I) abdomen of zoea I of Hippolyte sp.; (J) telson of zoea I of Palaemon adspersus; (K) abdomen of zoea I of Crangon crangon; (L) abdomen of zoea I of Philocheras monacanthus; (M) zoea I of Lysmata seticaudata; (N) last zoeal stage of Pasiphaea sivado; $(\mathrm{O})$ antennule of zoea I of Philocheras monacanthus; $(\mathrm{P})$ antennal scale of zoea III of Pontonia pinnophylax; (Q) pereiopods I-V of zoea I of Alpheidae; (R) fifth pereiopod of Pasiphaea. (A, redrawn from Fincham \& Williamson, 1978; B, from Williamson, 1957; C, from Gurney \& Lebour, 1941; D, from Bourdillon-Casanova, 1960; F (as Parapandalus richardi), from Lebour, 1940; G, from Williamson, 1960; H, from Gurney, 1942; L, O, from González-Gordillo et al., 2000; N, from Williamson, 1960a; P, from Calafiore et al., 1991). 
38. (a) Telson posterior margin enlarged, with 20 or more setae (Figure 5N) . . . . . . . . Genus Pasiphaea (b) Without these above characters. . Genus Systellaspis

39. (a) Bases of antennules separated by more than width of one of them (Figures 3D; 4A, E, F) . . . . . 40 (b) Bases of antennules close or separated by not more than width of one of them (Figure 4B, H) . . . . 43

40. (a) Endopods of third maxilliped, first and second pereiopod expanded (Figure 5B) ... . Genus Caridion (b) Endopods not expanded (Figure 5A) . . . . . 41

41. (a) Rostrum never toothed; antennal scale never segmented (Figure 4F) . . . . . . . . Genus Processa (b) Rostrum with small teeth (Figure 5F) or antennal scale segmented at tip (Figure 4E) . . . . . . . 42

42. (a) First to third pereiopods bearing exopods . . . . . .................. Pandalina brevirostris (b) First to fourth pereiopods bearing exopods (Figure 3D)................... Genus Stylopandalus

43. (a) Rostrum short (Figures 3D; 4F) . . . . . . 45 (b) Rostrum long. . . . . . . . . . . . . . . 44

44. (a) Carapace with 1-3 dorso-median teeth on the anterior part (Figure 5A) . . . . . . . Genus Palaemon (b) Very large dorso-median spine on third abdominal somite (Figure $5 \mathrm{G}$ ) . . . . . . . Genus Pontophilus

45. Third abdominal somite with a dorso-median spine (Figures 3I; 5G) .............. . 46 (b) Third abdominal somite without dorso-median spine (Figure 5L) . . . . . . . . . . . 47

46. (a) Dorso-median spine on third abdominal somite very large (Figure 5G). . . . . . . Genus Pontophilus (b) Dorso-median spine on third abdominal somite small (Figures 3I; 5K) . . . . . . . . . . . 46

47. (a) Fifth abdominal somite with a pair of dorso-lateral spines (Figure $5 \mathrm{~K}$ )........... Crangon crangon (b) Fifth abdominal somite without dorso-lateral spines; endopod of antennule bigger than the body and segmented (Figure 3I) . . . . . . Genus Aegaeon

48. (a) Eyes rounded; rostrum enlarged at base; endopod of antennule cylindrical shaped (Figures $4 \mathrm{H} ; 5 \mathrm{O}$ ). . . ............ Genus Philocheras, Crangon almanni (b) Rostrum narrow; endopod of antennule long and

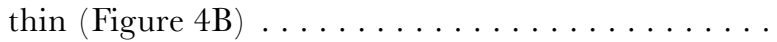
... . Genus Hippolyte, Genus Eualus or Genus Thoralus

\section{KEY 3-Infraorder ASTACIDEA}

(Figure 2B, G)

1. (a) Telson posteroexternal spines very long; fourth and fifth abdominal somites with a long dorsally directed median spine (Figure 2B) . . . . . Nephrops norvegicus (b) Telson posteroexternal spines very short; second to fourth abdominal somites with a short posterior directed median spine (Figure 2G) . . Homarus gammarus

\author{
KEY 4-Infraorder THALASSINIDEA \\ (Figures 1F, H; 2F, H; 6A-F, H, I, L)
}

1. (a) Anterior part of carapace elongated; antennae and eyes separated from mouthparts (Figure $1 \mathrm{~F}$ ) . . . . . . .................... Jaxea nocturna (b) Anterior part of carapace never elongated; antennae near the mouthparts $($ Figure $1 \mathrm{H}) \ldots \ldots \ldots 2$

2. (a) Abdominal segments without dorsal spines ...... ..................... (Genus Upogebia) 3 (b) At least one abdominal segment with dorsal spines (Figures $2 \mathrm{~F} ; 6 \mathrm{~A}, \mathrm{~B}) \ldots \ldots \ldots \ldots \ldots$

3. (a) Endopod of first maxilliped with 3, 2, 1, 2+1, 4 setae . . . . . . . . . . Upogebia deltaura (b) Endopod of first maxilliped with 3, 2+1, 1, 2+1, 4 setae (Figure 6L)........... Upogebia pusilla

4. (a) Fifth abdominal somite without lateral spines . . 5 (b) Fifth abdominal somite with two pairs of dorsolateral spines; four pairs of pleopods; telson triangular with posterior central margin slightly concave (Figure $2 \mathrm{~F}) \ldots \ldots \ldots \ldots \ldots \ldots \ldots$ Axius stirhynchus

5. (a) Posterior central margin of the telson slightly concave, without a distinct central seta (Figure 6C, D)

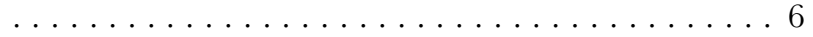
(b) Posterior margin of the telson with differenciated central spine (Figure 6E, F, H, I).(Genus Callianassa) 7

6. (a) Posterior margin of the telson with 18-19+18-19 setae (Figure 6D) .......... Calocaris macandreae (b) Posterior margin of the telson with $22-23+22-23$ setae (Figure 6C) . . . . . . . C Calocarides coronatus

7. (a) Telson spine formula: 7-9+1+7-9 (Figure 6F) . 8 (b) Telson spine formula: 13-18+1+13-18 (Figure $6 \mathrm{E}, \mathrm{H}) \ldots \ldots \ldots \ldots \ldots$

8. (a) All ventral margin of carapace denticulate (Figure $6 \mathrm{~A})$; second abdominal somite with very long median dorsal spine reaching the fifth abdominal somite; first spine of telson denticulate (Figure 6I) . . . . . . . . . . . . . . . . . . . . Callianassidae SL16 (b) When present, denticles only on the anterior ventral margin of carapace (Figure 6B); second abdominal somite reaching only to the fourth abdominal somite (Figure $1 \mathrm{H}$ ); first spine of telson without denticles (Figure $6 \mathrm{~F}) \ldots \ldots \ldots \ldots \ldots$

9. (a) Six abdominal somites, without medio-dorsal spine on sixth one; uropods present from zoea II . . . . . . . .

. Callianassa subterranea (b) Five abdominal somites in zoea I; medio-dorsal spine on sixth abdominal somite when presents (Figure 6B); uropods present from zoea III .Callianassa truncata

10. (a) Three zoeal stages: zoea I with median telson spine the same size as the others spines, zoea II without uropods, zoea III with exopod of uropods well developed (Figure $6 \mathrm{H}$ ); telson spine formula: 14, $1,14 \ldots \ldots \ldots \ldots \ldots \ldots \ldots$ Callianassa tyrrhena 

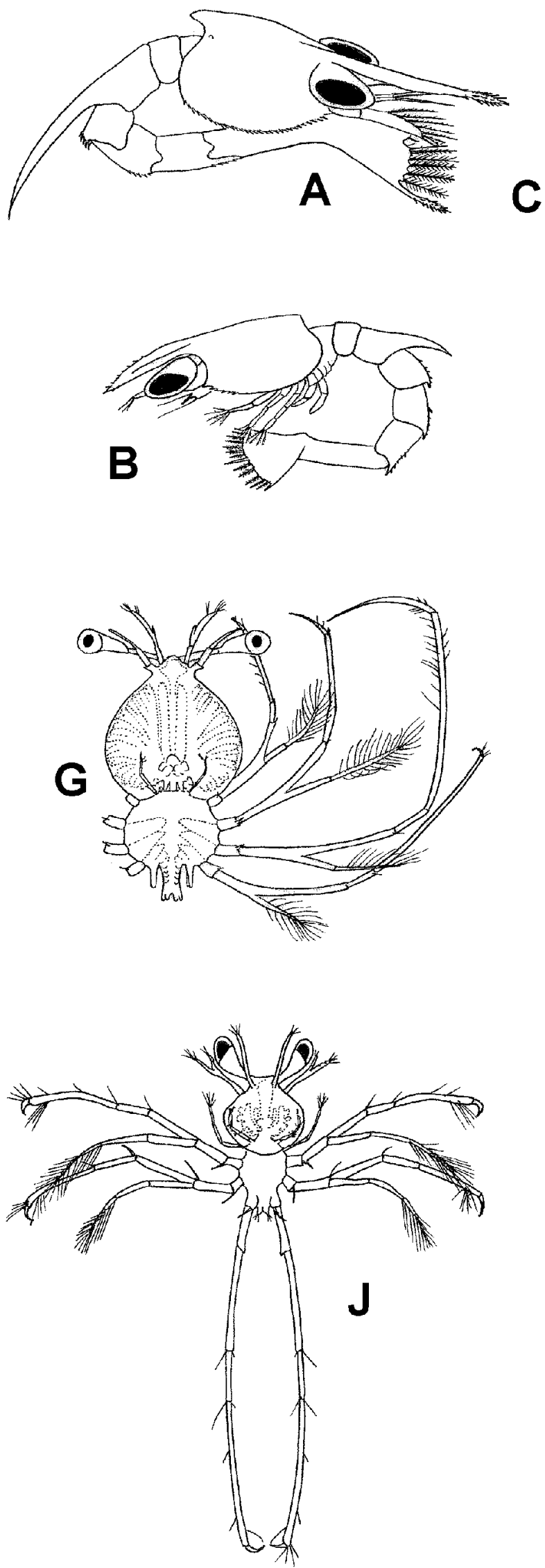
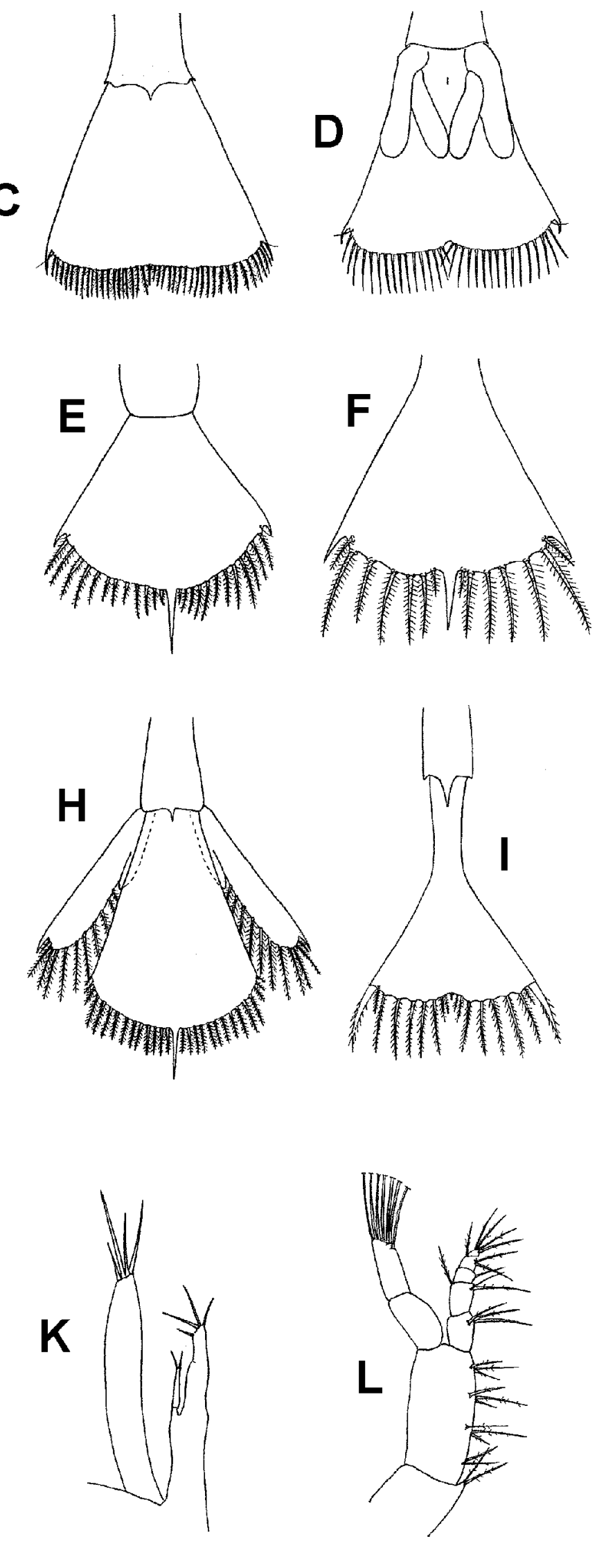

Figure 6. General aspects and appendages of thalassinidean and palinuran larvae. (A) Zoea I of Callianassidae SL16; (B) zoea I of Callianassa truncata; (C) telson of zoea II of Calocarides coronatus; (D) telson of zoea II of Calocaris macandreae; (E) telson of zoea I of Callianassidae L17; (F) telson of zoea I of Callianassa subterranea; (G) zoea III of Palinurus elephas; (H) telson of zoea III of Callianassa tyrrhena; (I) telson of zoea I of Callianassidae SL16; (J) zoea I of Scyllarides latus; $(\mathrm{K})$ antennule and antena of zoea I of Scyllarides latus; (L) first maxilliped of zoea II of Upogebia pusilla. (A, B, H, I, redrawn from dos Santos, 1999; C, Elofsson (1959); D, F, G from Gurney, 1942; J, K, from Santucci, 1925). 

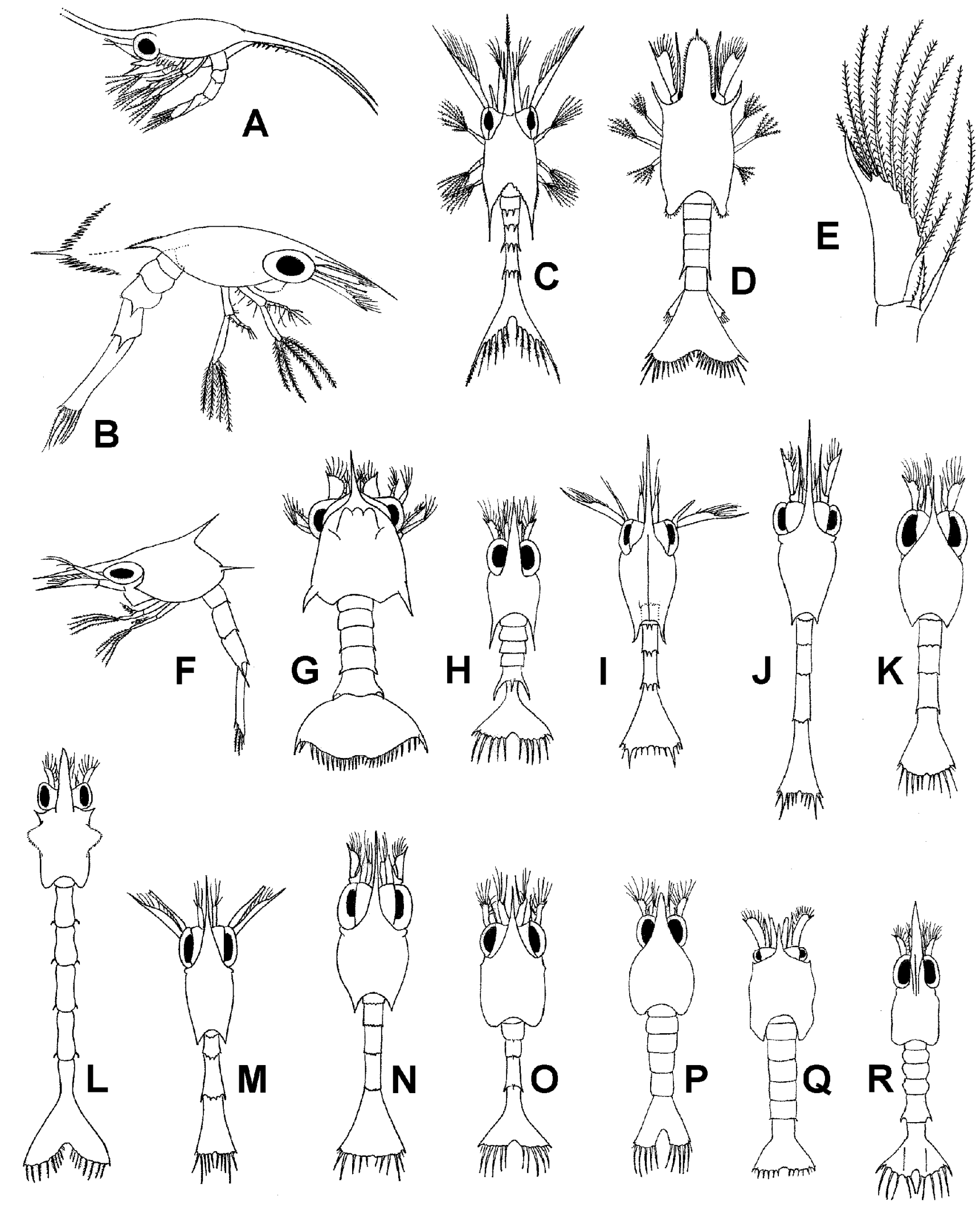

Figure 7. General aspects and appendages of anomuran larvae. (A) Zoea I of Pisidia longicornis; (B) zoea I of Galathea squamifera; (C) zoea II of Munida rugosa; (D) zoea I of Munidopsis tridentata; (E) antena of Zoea I of Galathea intermedia; (F) zoea I of Nematopagurus longicornis; (G) zoea I of Albunea carabus; (H) zoea I of Calcinus tubularis; (I) zoea I of Pagurus alatus; (J) zoea I of Pagurus bernhardus; (K) zoea I of Pagurus anachoretus; (L) zoea I of Parapagurus pilosimanus; (M) zoea I of Pagurus pubescens; (N) zoea I of Anapagurus laevis; (O) zoea I of Diogenes pugilator; (P) zoea I of Clibanarius erythropus; (Q) zoea I of Paguristes eremita; (R) zoea I of Dardanus arrosor. (B, redrawn from Ingle, 1992; C (as M. banffica), from Lebour, 1930; D, from Pike \& Williamson, 1972; E, from Christiansen \& Anger, 1990; F, (as Species N.3); H, (as Calcinus tubularis); K, P, Q (as Paguristes oculatus); R, from Pike \&

Williamson, 1960; G, from Seridji, 1988; I (as Pagurus variabilis), from Samuelsen, 1972; J, M, N, O, from Pike \& Williamson, 1958; L, from Saint Laurent, 1964). 
(b) Two zoeal stages: zoea I with median telson spine longer than the others (Figure 6E), zoea II with buds of uropods; telson spine formula: $17,1,17 \ldots \ldots \ldots$ . . . . . . . . . . . . Callianassidae L17

\section{KEY 5 - Infraorder PALINURA (excluding Family} Polychelidae)

(Figures 1D; 6G, J, K)

1. (a) Third maxilliped without exopod (Figures 1D; 6J) ................ (Family Scyllaridae) 2 (b) Third maxilliped with exopod (Figure 6G) . . . .

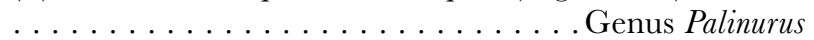

2. (a) Carapace pear-shape; antennule with exopod in first zoea (Figure 6K); third pereiopod larger than second pereiopod (Figure 6J) . . . . . . Scyllarides latus (b) Carapace as long as width; antennule without exopod in first zoea (Figure $1 \mathrm{H}$ ); third pereiopod the same size as second pereiopod (Figure 1D) . . . . . . .

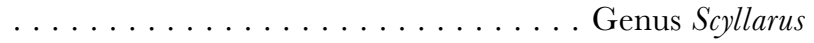

\section{KEY 6 - Infraorder ANOMURA}

(Figures 1E, I; 2A, I, 7A-R)

1. (a) Posterio-lateral margin of carapace extended into a spinous process (Figures 1E, I; 7F-K, M,N) . . . . . 2 (b) Posterio-lateral margin of carapace rounded (Figure $7 \mathrm{~L}, \mathrm{O}, \mathrm{Q}, \mathrm{R}) \ldots \ldots \ldots \ldots \ldots$

2. (a) Rostrum much longer than body; posterio-lateral margin process of carapace extended beyond the end of telson (Figures 1E; 7A) . . . . . (Family Porcellanidae) 3 (b) Rostrum shorter than body; posterio-lateral margin process of carapace never extending beyond the end of telson (Figures 1I; 7B, F-K, M, N) . . . . . . 4

3. (a) Posterior carapace spines at least half length of rostrum, without conspicuous ventral spines (Figure 1E) or with pleopods on second to fifth abdominal somites .............. Porcellana platycheles (b) Posterior carapace spines less than half length of rostrum, with two conspicuous ventral spines (Figure 7A) or with pleopods on second to fourth abdominal somites ............... Pisidia longicornis

4. (a) Posterolateral margins of carapace denticulate (Figure 7B-D) . . . . . . . (Family Galatheidae) 5 (b) Posterolateral margins of carapace without denticles but with terminal spine (Figures $1 \mathrm{I} ; 7 \mathrm{~F}-\mathrm{K}$, $\mathrm{M}, \mathrm{N}) \ldots \ldots \ldots \ldots \ldots \ldots \ldots \ldots \ldots \ldots \ldots \ldots \ldots$

5. (a) Antennal exopod aciculate; rostrum narrower than diameter of eye (Figure 7G) . . . . . . Genus Munida (b) Antennal exopod flattened (Figure 7E); rostrum narrower than diameter of eye (Figure $7 \mathrm{~B}) \ldots \ldots \ldots$ $\ldots \ldots \ldots \ldots \ldots$. . . . . . . . Falathea (c) Antennal exopod flattened; rostrum broader than diameter of eye (Figure 7D)..... Genus Munidopsis

6. (a) Carapace with a median dorsal spine (Figure $7 \mathrm{~F}$ ) ................. Nematopagurus longicornis (b) Carapace without median dorsal spine (Figure $7 \mathrm{G}-\mathrm{K}, \mathrm{M}, \mathrm{N}) \ldots \ldots \ldots \ldots \ldots$

7. (a) Telson strongly enlarged posteriorly with the outer posterior spines large, the same length as the rest of telson; spine formula: 6-7+6-7 . . Spiropagurus elegans (b) Telson enlarged, broader than long with three short anterior carinae; spine formula: 15-19+15-19 (Figure $7 \mathrm{G}) \ldots \ldots \ldots$............. Albunea carabus (c) Telson not enlarged and outer posterior spines not enlarged and never the same length as rest of telson; spine formula: 6-7+6-7 (Figure $7 \mathrm{H}-\mathrm{K}, \mathrm{M}, \mathrm{N}$ ). . 8

8. (a) Fifth abdominal somite with a pair of lateral spines and a median dorsal one (Figure $7 \mathrm{H}) \ldots \ldots \ldots$

$\ldots \ldots \ldots \ldots$. . . . . . . . . . . . . . . . . .

(b) Fifth abdominal somite with a pair of lateral spines and without or with more than one dorsal spine (Figure 7I-K, M) . . . . . . . . (Genus Pagurus) 9 (c) Fifth abdominal somite without or with very small lateral spines and without median dorsal spine (Figure $7 \mathrm{~N}) \ldots \ldots \ldots \ldots$. . . . . . . . . Anupagurus

9. (a) Carapace with median dorsal carina (Figure

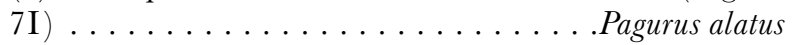
(b) Carapace without median dorsal carina (Figure

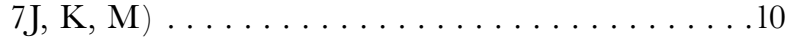

10. (a) Longest telson spine longer than half greatest width of telson; length of antennal scale (excluding terminal spine) at least six times breadth (Figure

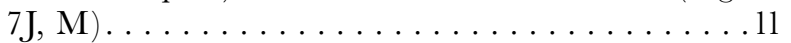
(b) Longest telson spine shorter than half greatest width of telson; length of antennal scale less than four times breadth (Figure $7 \mathrm{~K}$ )........ Pagurus spp.

11. (a) Fifth abdominal somite with large lateral spines; rostrum reaching around as far as spine on antennal scale (Figure $7 \mathrm{M}) \ldots \ldots \ldots \ldots$. . . Pagurus pubescens (b) Fifth abdominal somite with small lateral spines; rostrum reaching well beyond spine on antennal scale (Figure $7 \mathrm{~J}$ ) . . . . . . . . . Pagurus bernhardus

12. (a) Fifth abdominal somite with a pair of ventral or lateral spines (Figures 2A; 7L, O, Q, R) . . . . . 13 (b) Abdominal somites without lateral spines; rostrum large and rounded on distal margin (Figure $7 \mathrm{P}) \ldots$ $\ldots \ldots \ldots \ldots \ldots$. . . . . . . .

13. (a) Second to fifth abdominal somites short, with small dorso-marginal spines (Figure 7O); telson posterior margin with a small $\mathrm{V}$-shaped cleft (Figure 2A) . . . . Diogenes pugilator (b) Second to fifth abdominal somites long, with small ventro-lateral spines (Figure $7 \mathrm{~L}$ ) . . . . . . . . ................ Parapagurus pilosimanus (c) Only the fifth abdominal somite with dorsomarginal spines (Figure 7Q, R) . . . . . . . 14 

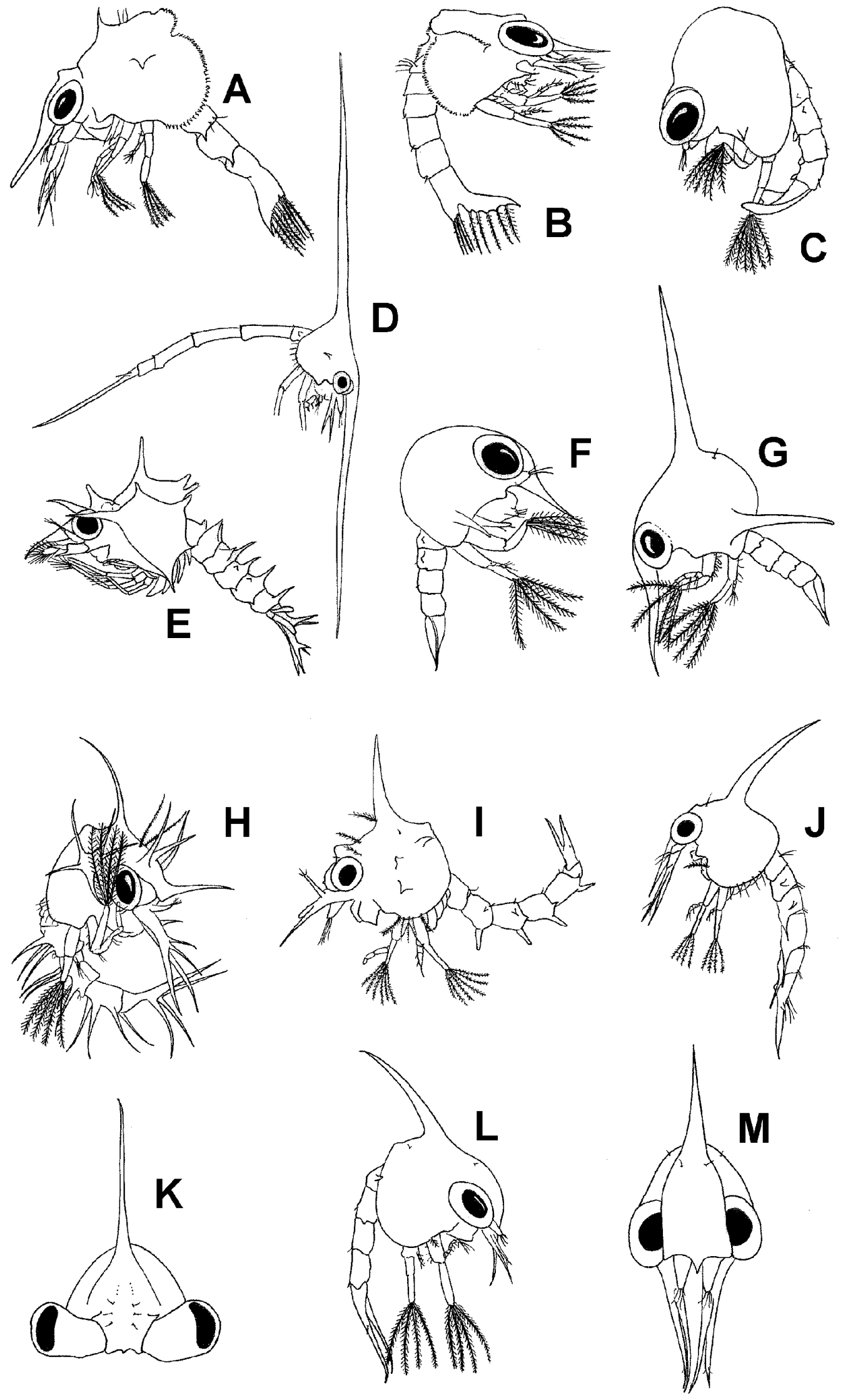

Figure 8. General aspects of brachyuran larvae. (A) Zoea I of Paromola cuvieri; (B) zoea I of (?) Latreillia elegans; (C) zoea III of Ebalia tuberosa; (D) zoea I of Ethusa mascarone; (E) zoea IV of Homola barbata; (F) zoea I of Pinnotheres pisum; (G) zoea I of Nepinnotheres pinnotheres; (H) zoea I of Dorhynchus thomsoni; (I) zoea II of Stenorhynchus lanceolatus; ( J) zoea I of Herbstia condyliata; (K) frontal aspect of carapace of zoea I of Inachus dorsettensis; (L) zoea I of Eurynome spinosa; (M) frontal aspect of carapace of zoea I of Pisa armata. (A, redrawn from Samuelsen, 1976; B, from Rice \& Williamson, 1977; C, from Salman, 1982; D, from Paula, 1993; E, from Rice \& Levetzow, 1967; F, G, H, K, L, M, from Ingle, 1992; I, from Paula \& Cartaxana, 1991; J, from BourdillonCasanova, 1960). 

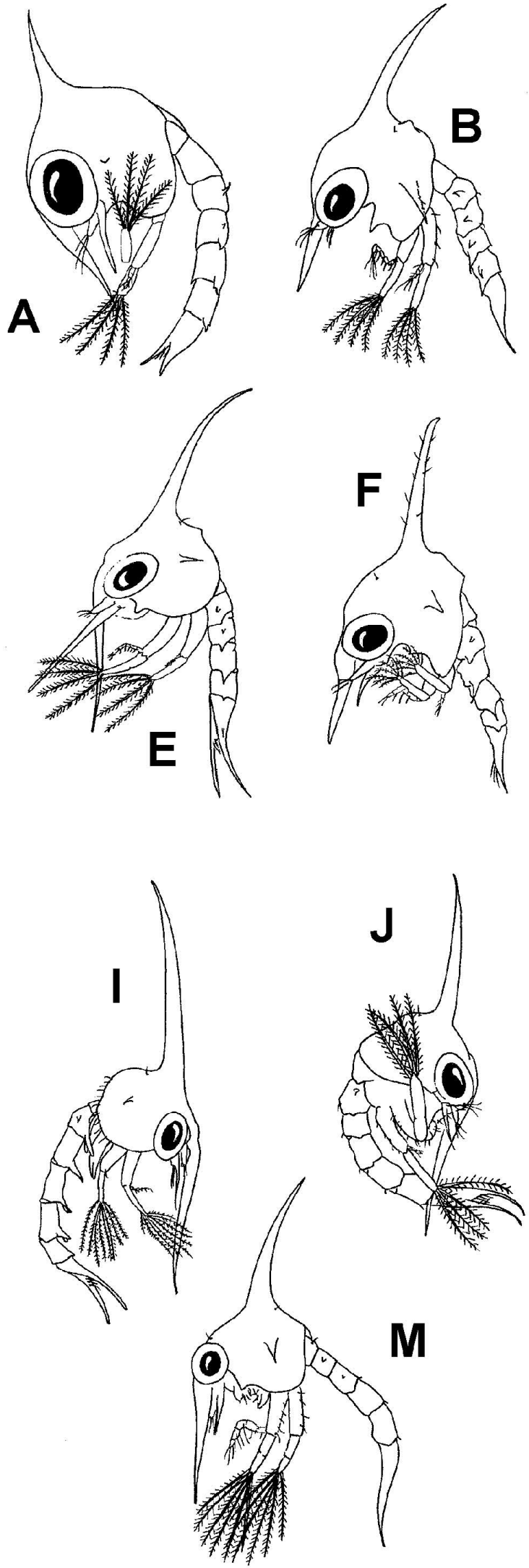
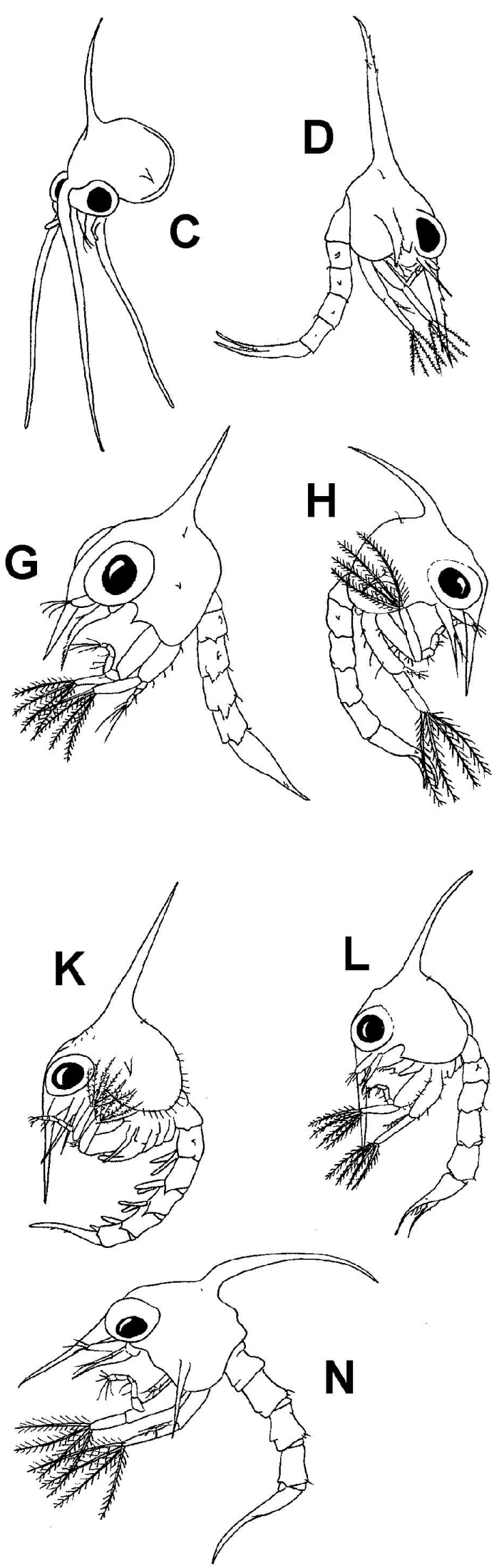

Figure 9. General aspects of brachyuran larvae. (A) Zoea I of Pachygrapsus marmoratus; (B) zoea I of Plagusia depressa; (C) carapace of zoea IV of Rhithropanopeus harrisii; (D) zoea I of Percnon gibbesi; (E) zoea I of Xantho incisus; (F) zoea III of Grapsinae ASM30; (G) zoea I of Planes minutus; (H) zoea I of Pirimela denticulata; (I) lateral aspect of zoea IV of Thia scutellata; ( J) zoea I of Portumnus latipes; (K) zoea V of Necora puber; (L) zoea I of Carcinus maenas; (M) zoea I of Brachynotus sexdentatus; (N) zoea I of Asthenognathus atlanticus. (A, redrawn from dos Santos, 1999; B, from Schubart et al., 2001; C, from Conolly, 1925; D, from Paula \& Hartnoll, 1989; E, from Ingle, 1983; F, from Rice \& Williamson, 1977; G, from Cuesta et al., 1997; H, from Ingle, 1992; I, from Ingle, 1984; J, K, from Ingle, 1992; L, from Rice \& Ingle, 1975; M, from Cuesta, 1999; N, from Bocquet, 1965). 
14. (a) Rostrum not reaching the end of antennule; cuticle smooth; zoea I with pleopod buds (Figure 7Q) .... $\ldots \ldots \ldots \ldots \ldots \ldots$. . . . . . . . . . . . . (b) Rostrum longer than antennule; cuticle scaly; zoea I without pleopod buds (Figure 7R). . Dardanus arrosor

\section{KEY 7 - Infraorder BRACHYURA}

(Figures 8, 9, 10, 11 \& 12)

1. (a) Antennal exopod well developed and flat, with long plumose setae; spinous process vestigial (Figure 11A) . . . . . . . . . . . . . Dromia personata (b) Antennal exopod well developed and flat, with long plumose setae; spinous process well developed (Figure 11B $\ldots \ldots \ldots \ldots \ldots \ldots \ldots \ldots \ldots \ldots \ldots$ (c) Antennal exopod well developed and styliform, spinous process well developed (Figures 11C, E-I, K, $\mathrm{L}-\mathrm{O}, \mathrm{T} ; 12 \mathrm{G}) \ldots \ldots \ldots \ldots \ldots \ldots$

2. (a) Dorso and dorso-lateral processes on abdominal somites 2-4; dorso-lateral spines on telson (Figure 8E) $\ldots \ldots \ldots \ldots \ldots \ldots$. . . . . . . . . . . . . barbata (b) No dorso-lateral processes on abdominal somites; no dorso-lateral spines on telson (Figure 10H) . . . 3

3. (a) Dorso and lateral carapace spines well differenciated (Figure 8A) . . . . . . . . . Paromola cuvieri (b) No prominent spines on carapace (Figure 8B) . . $\ldots \ldots \ldots \ldots \ldots \ldots$. . . . L . Latreillia elegans

4. (a) Very long furca with a maximum of $2+2$ posterior processes (Figure 10Q); carapace rostral and dorsal spines very long (Figure 8D) . (Family Dorippidae) 5

(b) Without this combination of characters . . . . 6

5. (a) Lateral spines on carapace (Figure 8D). . . . . . . . . . . . . . . . . . . . . Ethusa mascarone (b) No lateral spines on carapace ....Medorippe lanata

6. (a) Telson as typical furca (Figure 10A-D, F, G, J, L,

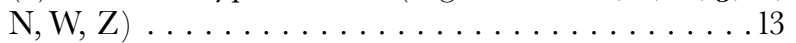
(b) Telson non furca type (Figure $10 \mathrm{~K}, \mathrm{M}) \ldots \ldots 7$

7. (a) Telson trilobed (Figure $10 \mathrm{~K}) \ldots \ldots \ldots \ldots$

(b) Telson with triangular shape (Figure 10M) .... ............... (Family Leucosiidae) 9

8. (a) Carapace with dorsal spine (Figure $8 \mathrm{G}$ ) . . . . . . . . . . . . . . . . . Nepinnotheres pinnotheres (b) Carapace without dorsal spine (Figure 8F) . . . . $\ldots \ldots \ldots \ldots \ldots \ldots \ldots$ Pinnotheres pisum

9. (a) Carapace with dorsal spine. . . . . . . . Ilia nucleus (b) Carapace without dorsal spine (Figure 8C) . . . . ...................... (Genus Ebalia) 10

10. (a) Endopod of maxillule two-segmented, with four setae on distal segment (Figure 12F) . . Ebalia tuberosa (b) Endopod of maxillule unsegmented, with three setae (Figure 12A) . . . . . . . . . . . . . 11

11. (a) Endopod of the first maxilliped with 2, 1, 1, 2, 5 setae (Figure 12M) . . . . . . . . . Ebalia nux (b) Endopod of the first maxilliped with 1, 1, 0, 2, 5 setae $($ Figure $12 \mathrm{~K}) \ldots \ldots \ldots \ldots$. . . . . . . . . 12

12. (a) Inter-orbital region 3-pointed (Figure 12D) .... $\ldots \ldots \ldots \ldots \ldots$. . . . . . Ebalia tumefacta (b) Inter-orbital region bilobed, with no central spine $\ldots \ldots \ldots \ldots$. . . . . Ebalia cranchii

13. (a) Two stages: first stage (four natatory setae on exopod of maxillipeds) with antennal endopod bud; second stage (six natatory setae on exopod of maxillipeds) with pleopod buds (Figure 8I); 'majid seta' on inner lateral margin of carapace (Figures 8I, 12N) . . .................. (Family Majidae) 14 (b) Four or more stages: first stage (four natatory setae on exopod of maxillipeds) without antennal endopod bud (Figures 11C, E-I, K-O, T; 12G); second stage (six natatory setae on exopod of maxillipeds) without pleopods; no 'majid seta' on inner lateral margin of carapace . . . . . . . . . . . . . . . . 27

14. (a) Lateral spines on carapace (Figure 8H, I) . . . . 15 (b) No lateral spines on carapace (Figure 8L) . . . . 19

15. (a) Carapace with more than one pair of lateral spines (Figure 8H, I) . . . . . . . . . . . . . . 16 (b) Carapace with one pair of lateral spines . . . . . 17

16. (a) Five pairs of lateral spines on carapace (Figure $8 \mathrm{H}$ ) ....................... Dorhynchus thomsoni (b) Three pairs of lateral spines on carapace (Figure 8I) . . . . . . . . . Stenorhynchus lanceolatus

17. (a) Third abdominal somite with dorso-lateral knobs (Figure 10A) . . . . . . . . . . . . . . . 18 (b) Third abdominal somite without dorso-lateral knobs (Figure 10B) . . . . . . . Rochinia carpenteri

18. (a) Branches of telson furca with one lateral and dorsal spine (Figure 10A) . . . . . . . . . . . Genus Hyas (b) Branches of telson furca with three lateral spines (Figure 10Z) . . . . . . . . . . . Genus Maja

19. (a) Rostral spine on carapace (Figure 8L, M) . . . 20

(b) No rostral spine on carapace (Figure 8K) . . . 25

20. (a) Rostral spine well developed (Figure 8L) . . . .21

(b) Rostral spine highly reduced (Figure 8M) . . 23

21. (a) Branches of telson furca with prominent lateral and dorsal spines (Figure 10D) . . . . . . Genus Eurynome (b) Branches of telson furca without dorsal spine (Figure 10E) . . . . . . . . . . . . . 22

22. (a) Dorso-lateral knobs on abdominal somites 2 and 3 (Figure $8 \mathrm{~J}$ ) . . . . . . . . . . Herbstia condyliata (b) Dorso-lateral knobs on abdominal somites 2-5 (Figure 10E) ............ Anamathia rissoana 
23. (a) Dorsal spine smaller than the diameter of the eye and armed with minute granular protuberances . . . . .................... Acanthonyx lunulatus (b) Dorsal spine bigger than the diameter of the eye and without protuberances............. 24

24. (a) Endopod of second maxilliped armed with 0, 2, 5 setae; antennule with one simple seta and 4-5 aesthetascs in zoea I or seven in zoea II .... Lissa chiragra (b) Endopod of second maxilliped armed with 0, 1, 5 setae; antennule with six aesthetascs in zoea I or eight aesthetascs in zoea II. . . . . . . . Genus Pisa

25. (a) Branches of telson furca with small lateral spine (Figure 10F) . . . . . . . . . . Genus Macropodia (b) Branches of telson furca with prominent lateral spine (Figure 10G, N) . . . . . . . . . . 26

26. (a) Each furca of telson with a stout and curved outer lateral spine measuring slightly less than one-third furcal length (Figure $10 \mathrm{G})$. . . . . . . Achaeus cranchii (b) Each furca of telson with a thin and relatively straight outer spine measuring much less than onethird of furcal length (Figure 10N) . . . Genus Inachus

27. (a) Antennal exopod highly reduced (Figures $11 \mathrm{C}, \mathrm{J}$;

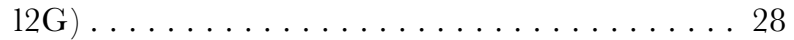
(b) Antennal exopod not reduced (Figure 11E-I,

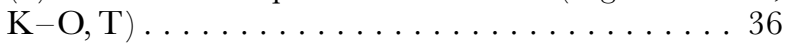

28. (a) Spinous process of antenna shorter than rostral spine (Figure 9A, B, D) . . . . . . . . . . . . 29 (b) Spinous process of antenna approximately of the length of rostral spine (Figure 9C, E) . . . . . . . 31

29. (a) Dorso-lateral knobs on abdominal somites 2-3 (Figure 10G) . . . . . . . . . Calappa granulata (b) Dorso-lateral knobs on abdominal somites 2-4 (Figure 9F) . . . . . . . . . . Grapsinae ASM30 (c) Dorso-lateral knobs on abdominal somites 2-5 (Figure 10I, O) . . . . . . . . . . . . 30

30. (a) Rostral and dorsal spines longer than carapace in stage I (Figure 9D) and very long in subsequent stages; branches of telson furca slender and longer than proximal part of telson from stage II, with deep median notch (Figure 10O); dorsal spine with spinules at the tip; lateral spines with expanded tips (Figure $12 \mathrm{O}) \ldots \ldots \ldots \ldots \ldots$. . . . . . . Percnon gibbesi (b) Rostral and dorsal spines no longer than carapace in stage I (Figure 9B); branches of telson furca slightly longer than proximal part of telson in all stages, with small median notch (Figure 10I) . . . Plagusia depressa

31. (a) Minute (zoea I) or well developed (later zoeas) lateral spines on carapace (Figure 9G) . . . . . . 32 (b) Well developed lateral spines on carapace (Figure $9 \mathrm{C}, \mathrm{E}) \ldots \ldots \ldots \ldots \ldots \ldots \ldots \ldots \ldots \ldots \ldots$

32. (a) Antennule bearing two long and two short aesthetascs (Figure 12G); three minute lateral spines on each telson furca (Figure 10W) . . . . . Grapsus adscensionis (b) Antennule bearing two long and one short aesthetascs (Figure 12H); two lateral spines on each telson furca (Figure 10Y)............. Planes minutes (c) Antennule bearing three to four aesthetascs; two lateral spines on each telson furca (Figure 10S) . . . . . ......................... Pachygrapsus

33. (a) Rostral spine longer than twice carapace length (Figure 9G); very long posteroventral spine on abdominal somite $5 \ldots$. . . . Rhithropanopeus harrisii (b) Rostral spine less than twice carapace length (Figure 9E) . . . . . . . . . . . . . 34

34. (a) Basal segment of endopod of the first maxilliped with two setae . . . . . . . Nanocassiope melanodactyla (b) Basal segment of endopod of the first maxilliped with three setae ............... 35

35. (a) Antennal exopod with one terminal seta (Figure $11 \mathrm{P}) \ldots \ldots \ldots \ldots \ldots$. . . . . . . . . . (b) Antennal exopod with two terminal setae (Figure 11D) . . . . . . . . . . Genus Xantho

36. (a) Dorso-lateral knobs on abdominal somite 2 only (Figure $9 \mathrm{H}-\mathrm{J}, \mathrm{L}$ ) . . . . . . . . . . . . . . 37 (b) Dorso-lateral knobs in more than one abdominal somite, at least in first stage (Figures 9M;10L) . . 45

37. (a) Lateral spines on carapace (Figure 9H, I) . . . 38

(b) No lateral spines on carapace (Figure 9L) . . . 43

38. (a) Telson with the inner margins of the outermost seta strongly serrate (Figure 10X) . . . . . . . . . . . 39 (b) Telson without this character (Figure 10T) . . 40

39. (a) First segment of endopod of the first maxilliped with three setae (Figure 12J) . . . . . . . Genus Cancer (b) First segment of endopod of the first maxilliped with two setae............ Genus Atelecyclus

40. (a) Branches of telson furca with a row of teeth (Figure 10T) . . . . . . . . . . . Brachynotus atlanticus (b) Telson without this character . . . . . . . . 41

41. (a) Dorsal and rostral carapace spines short, usually not exceeding carapace length (Figure 9H); antennal spinous process only just exceeding twice exopod length (Figure 11E) . . . . . . . . Pirimela denticulata (b) Dorsal and rostral carapace spines long, well exceeding carapace length (Figure 9I); antennal spinous process exceeding twice exopod length, at least in first stage (Figure 11L) . . . . . . . . . 42

42. (a) First segment of endopod of the first maxilliped with three setae........... Corystes cassivelaunus (b) First segment of endopod of the first maxilliped with two setae . . . . . . . . . . Thia scutellata

43. (a) Antennal exopod with two subterminal spines (Figure 11Q) ............. Sirpus zariquieyi (b) Antennal exopod with one subterminal spine (Figure $11 \mathrm{~N}) \ldots \ldots \ldots \ldots \ldots \ldots 4$ 

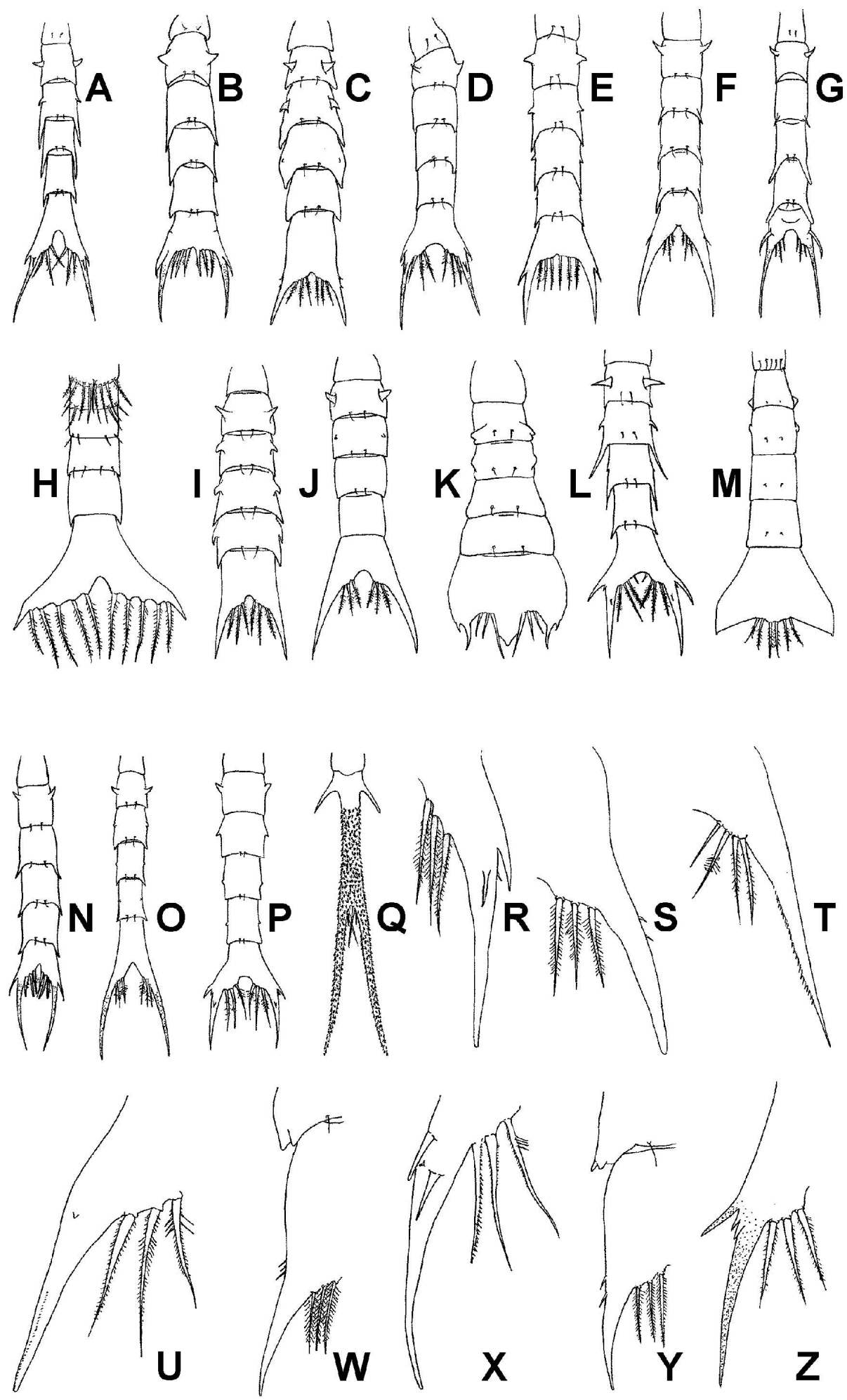

Figure 10. Telsons and abdomens of brachyuran larvae. (A) Zoea I Hyas araneus; (B) zoea I of Rochinia carpenteri; (C) zoea II of Pachygrapsus transversus; (D) zoea I of Eurynome spinosa; (E) zoea I of Anamathia rissoana; (F) zoea I of Macropodia parva; (G) zoea I of Achaeus cranchii; (H) zoea I of Paromola cuvieri; (I) zoea I of Plagusia depressa; ( J) zoea I of Brachynotus sexdentatus; (K) zoea I of Pinnotheres pisum; (L) zoea II of Geryon longipes; (M) zoea III of Ebalia tuberosa; (N) zoea I of Inachus dorsettensis; (O) zoea II of Percnon gibbesi; (P) zoea I of Eriphia verrucosa; (Q) zoea I of Ethusa mascarone; (R) right furca of telson of zoea I of Calappa granulata; (S) right furca of telson of zoea II of Pachygrapsus maurus; (T) right furca of telson of zoea III of Brachynotus atlanticus; (U) left furca of telson of zoea I of Uca tangeri; (W) left furca of telson of zoea I of Grapsus adscensionis; (X) left furca of telson of zoea I of Atelecyclus rotundatus; (Y) left furca of telson of zoea I of Planes minutus; (Z) left furca of telson of zoea I of Maja goltziana. (A, redrawn from Christiansen, 1973; B, from Ingle, 1979; C, J, S, from Cuesta, 1999; D, K, M, N, X, from Ingle, 1992; E, from Guerao \& Abelló, 1996; F, from González-Gordillo \& Rodríguez, 2001; G, from Bocquet, 1954; H, from Samuelsen, 1976; I, from Schubart et al., 2001; L, from dos Santos, 1999; O, from Paula \& Hartnoll, 1989; P, from Lumare \& Gozzo, 1972; Q, from Paula, 1987; R, from Guerao et al., 1998; T, from Rodríguez et al., 1992; U, from Paula, 1985; W, Y, from Cuesta et al., 1997; Z, from Paula, 1988). 

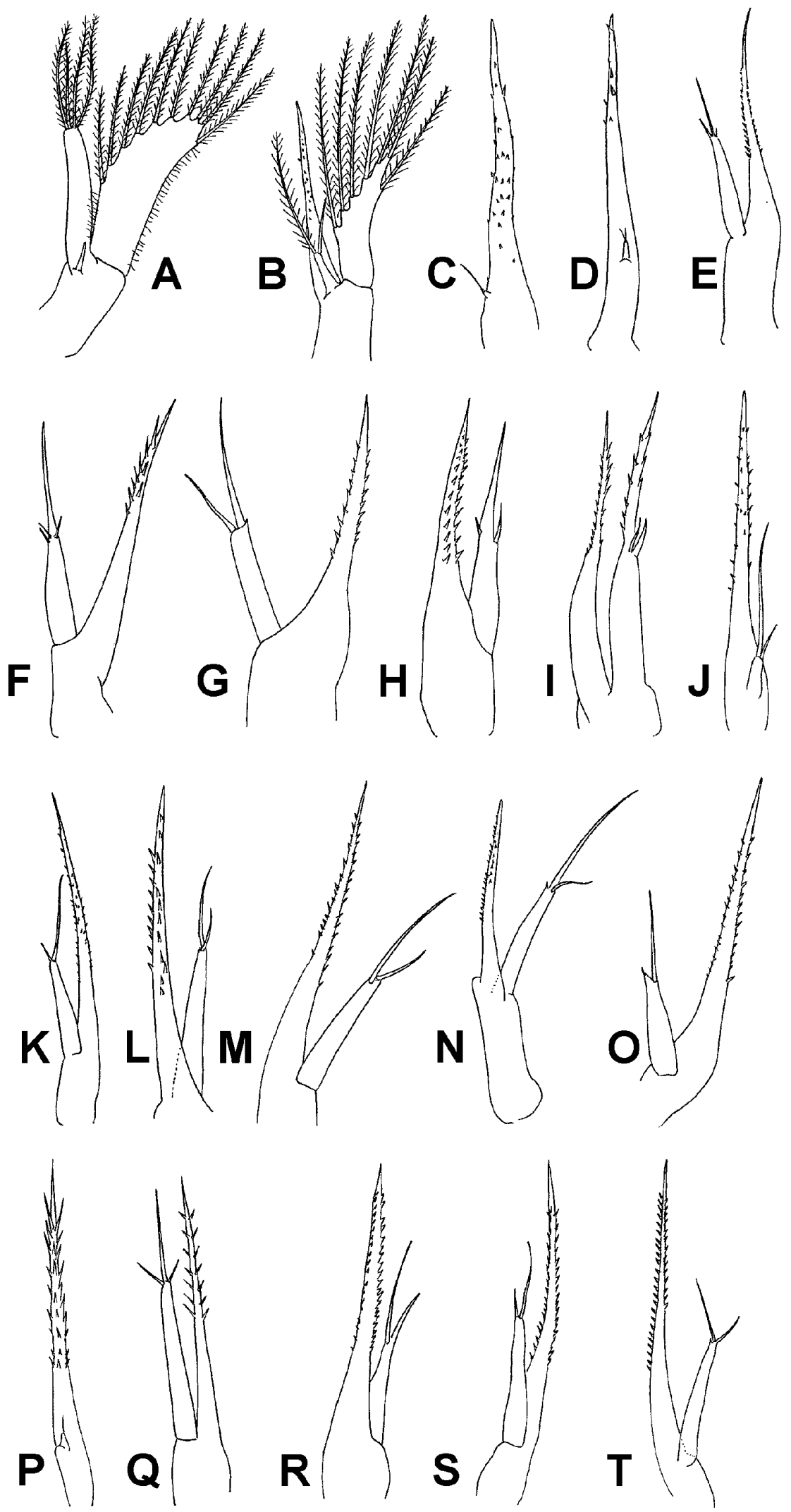

Figure 11. Antennas of brachyuran larvae. (A) Zoea I of Dromia personata; (B) zoea I of Paromola cuvieri; (G) zoea I of Pachygrapsus marmoratus; (D) zoea I of Xantho incisus; (E) zoea I of Pirimela denticulata; (F) zoea I of Goneplax rhomboides; (G) zoea I of Uca tangeri; (H) zoea I of Brachynotus sexdentatus; (I) zoea I of Pilumnus hirtellus; ( $\mathrm{J}$ ) zoea I of Calappa granulata; (K) zoea II of Bathynectes longipes; (L) zoea I of Corystes cassivelaunus; (M) zoea I of Liocarcinus corrugatus; (N) zoea I of Carcinus maenas; (O) zoea I of Polybius henslowii; (P) zoea I of Panopeus africanus; (Q) zoea I of Sirpus zariquieyi; (R) zoea I of Geryon trispinosus; (S) zoea I of Macropipus tuberculatus; (T) zoea I of Necora puber. (A, D, E, F, I, L, M, N, T, redrawn from Ingle, 1992; B, from Samuelsen, 1976; C, from Ingle, 1987; G, O, from Paula, 1985; H, from Cuesta et al., 2000; J, from Guerao et al., 1998a; K, from Ingle, 1985; P, from Rodríguez \& Paula, 1993; Q, from Bourdillon-Casanova, 1960; R, (as Geryon tridens), from Brattegard \& Sankarankutty, 1967; S, from Guerao \& Abelló, 1999). 

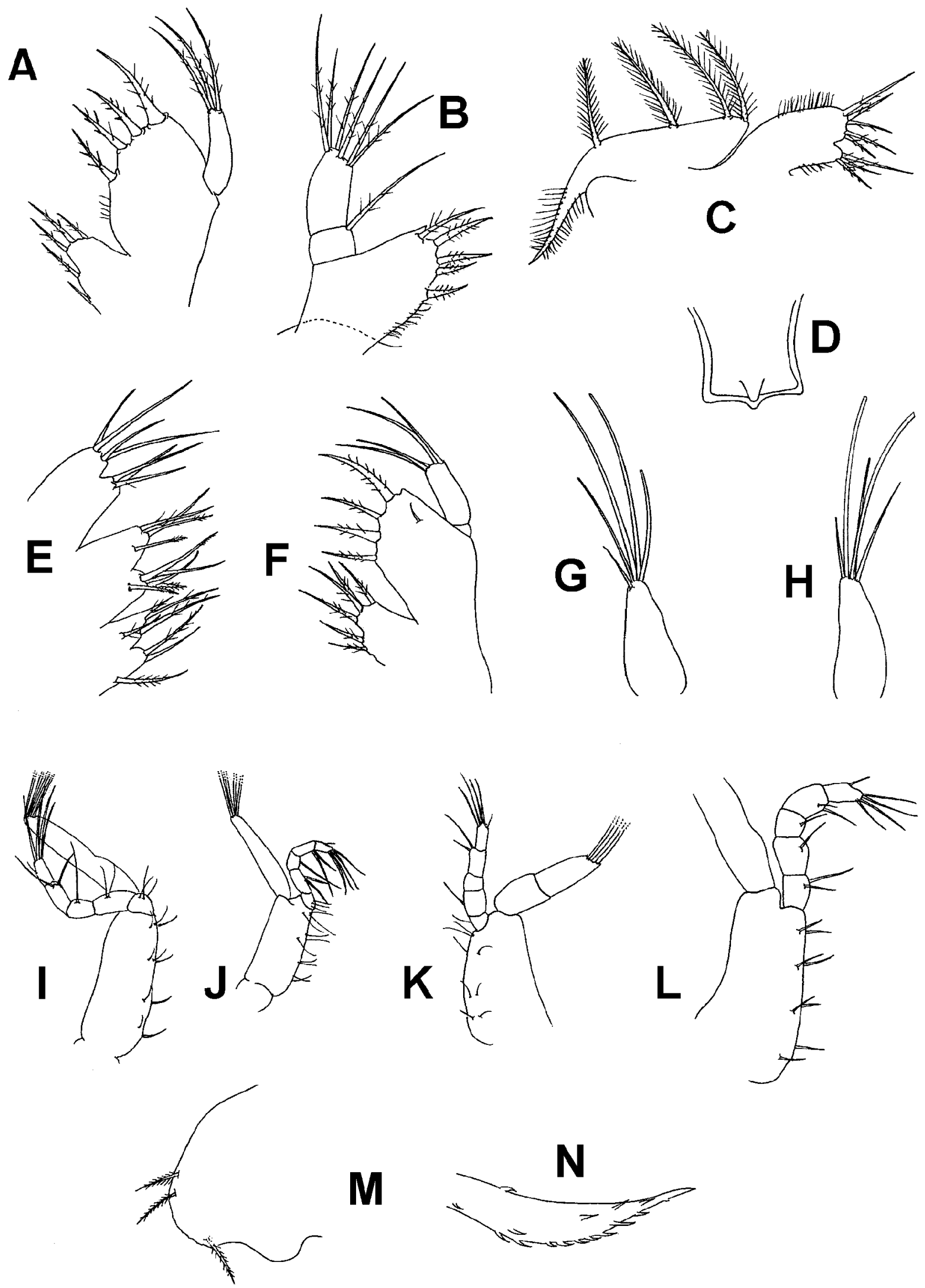

Figure 12. Appendages of brachyuran larvae. (A) Maxillule of zoea I of Ebalia tumefacta; (B) maxillule of zoea I of Polybius henslowii; (G) endopod of maxilla of zoea I of Polybius henslowii; (D) inter-orbital region of zoea I of Ebalia tumefacta; (E) maxilla of zoea I of Necora puber; (F) maxillule of zoea I of Ebalia tuberosa; $(\mathrm{G})$ antennule of zoea I of Grapsus adscensionis; $(\mathrm{H})$ antennule of zoea I of Planes minutus; (I) first maxilliped of zoea I of Monodaeus couchii; ( $\mathrm{J}$ ) first maxilliped of zoea I of Cancer pagurus; (K) first maxilliped of zoea I of Ebalia tumefacta; (L) first maxilliped of zoea I of Ebalia nux; (M) lateral aspect of carapace of zoea I of Macropodia parva; (N) lateral spine of carapace of zoea II of Percnon gibbesi. (A, redrawn from Salman, 1982; B, C, from Paula, 1985; D, E, from Ingle, 1992; F, from Salman, 1982; G, H, from Cuesta et al., 1997; I, from Ingle, 1983; J, from Ingle, 1981; K, from Salman, 1982; L, from Rice, 1980; M, from González-Gordillo \& Rodríguez, 2001; N, from Paula \& Hartnoll, 1989). 
44. (a) Dorsal spine curved and nearly the same length as carapace (Figure 9L) . . . . . . . . Genus Carcinus (b) Dorsal spine straight and nearly 1.5 the length of carapace (Figure 9J) ...........Portumnus latipes

45. (a) Dorso-lateral knobs on abdominal somites $2-4$ or 2-5 (Figure 10L, P) ............ 46 (b) Dorso-lateral knobs on abdominal somites 2 and 3 (Figures $9 \mathrm{M} ; 10 \mathrm{~J}) \ldots \ldots . \ldots . \ldots . \ldots . . .49$

46. (a) Branches of telson furca without spines ....... $\ldots \ldots \ldots \ldots \ldots \ldots$ Eriocheir sinensis (b) Branches of telson furca with two or three spines (Figure 10L, P) . . . . . . . . . . . . 47

47. (a) Antennal exopod almost as long as spinous process (Figure $11 \mathrm{~F}$ ) ............ Goneplax rhomboides (b) Antennal exopod shorter than spinous process (Figure 11R) . . . . . . . . . . . . . 48

48. (a) Dorso-lateral knobs on abdominal somites 2-4 (Figure 10L) . . . . . . . . . . Family Geryonidae (b) Dorso-lateral knobs on abdominal somites 2-5 (Figure $10 \mathrm{P}) \ldots \ldots \ldots \ldots$. . . . Eriphia verrucosa

49. (a) Branches of telson furca with a row of teeth (Figure $10 \mathrm{U}) \ldots \ldots \ldots \ldots \ldots \ldots$

(b) Telson without this character . . . . . . . 52

50. (a) Antennal exopod with two terminal setae (Figure $11 \mathrm{G}) \ldots \ldots \ldots \ldots \ldots \ldots$. . . . . . tangeri (b) Antennal exopod distally prolonged into a spine, with two median spines (Figure $11 \mathrm{H}$ ) . . . . . . .51

51. (a) Dorsal spine long and curved; lateral spines thin and measuring more than half carapace length (Figure 9N) ........... Asthenognathus atlanticus (b) Dorsal spine long and straight; lateral spines measuring less than half carapace length (Figure $9 \mathrm{M}) \ldots \ldots \ldots \ldots \ldots$. . . . . . . . . .

52. (a) Antennal exopod as long as spinous process (Figure 11I) . . . . . . . . . . . Genus Pilumnus (b) Antennal exopod shorter than spinous process (Figure 11K, M, O, T) ............ 53

53. (a) First segment of endopod of the first maxilliped with three setae (Figure 12I) . . . . . Monodaeus couchii (b) First segment of endopod of the first maxilliped with two setae . . . . . . . . . . . . . 54

54. (a) First segment of endopod of the maxillule without a seta ........... (Family Parthenopidae) 55 (b) First segment of endopod of the maxillule with one seta (Figure 12B) . . . . . . . . . . . 56

55. (a) Third segment of endopod of the first maxilliped without seta. . . . . . . . . Heterocrypta maltzani (b) Third segment of endopod of the first maxilliped with one seta............ Genus Parthenope

56. (a) Antennule with five or six aesthetascs . . . . . . . . . . . . . . . . . . Genus Liocarcinus (part) (b) Antennule with four aesthetascs . . . . . . . . . 57

57. (a) Endopod of maxilla with $3+5$ setae (Figure 12G)

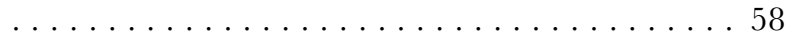
(b) Endopod of maxilla with $3+4$ setae (Figure 12E) . . . . . . . . . . . . . . . . . . . . 59

58. (a) Antennal exopod highest seta extending as far as $1 /$ 3 spinous process (Figure 11M). . Liocarcinus corrugatus (b) Antennal exopod highest seta not extending $1 / 3$ spinous process (Figure 11O) . . . . Polybius henslowii (c) Antennal exopod highest seta just extending 1/3 spinous process (Figure 11K) ..... Genus Bathynectes

59. (a) Antennal exopod highest seta just extending $1 / 3$ spinous process (Figure 11T); from zoea III (exopod of first and second maxillipeds with eight setae) the dorso-lateral process absent in abdominal somite 3 (Figure 9K) ........................ (b) Antennal exopod highest seta extending well into 1/3 spinous process (Figure 11S); zoea III (exopod of first and second maxillipeds with eight setae) with dorso-lateral process present in abdominal somite 3 . ................. Macropipus tuberculatus

\section{Identification of the Pleocyemata zoeal stages}

It is so difficult to provide a list of characters by which each larval stage can be recognized as a group because there are a wide variation of forms and number of instars in the development among decapod species. We can distinguish each larval stage by a combination of characters shared by most instars, while exceptions to each combination are noted.

\section{Infraorder BRACHYURA}

The counting of number of distal setae on the exopods of maxillipeds is enough for the identification of zoeal stages of brachyuran larvae. In the zoea I stage there are four setae, in zoea II six setae, in zoea III eight setae, etc.

\section{The other Pleocyemata}

Zoea I: sessile eyes; abdomen with five somites; pleopods and uropods absent.

Exceptions: Athanas nitescens having mobile eyes; Chlorotocus crassicornis, Infraorder Astacidea and Family Callianassidae having the abdomen with six somites; Family Pasiphaeidae having pleopod buds and eyes semi-mobiles; Palaemonetes zariquieyi, Family Axiidae and Family Calocarididae having the abdomen with six somites and pleopod buds; Family Polychelidae having the abdomen with six somites and pleopod and uropod buds.

Zoea II: mobile eyes; abdomen with five somites; pleopods and uropods absent.

Exceptions: Family Porcellanidae (last stage) and Family Pasiphaeidae having pleopod buds; Family 
Callianassidae having the abdomen with six somites and uropods buds; Palaemonetes zariquieyi, Infraorder Astacidea, Family Axiidae (last stage) and Family Calocarididae having the abdomen with six somites and pleopod buds.

Zoea III: abdomen with six somites; uropods present (endopod rudimentary); pleopods absent; antennal exopod segmented on distal margin.

Exceptions: Infraorder Stenopodidea, Synalpheus, Hippolyte, Family Processidae, Family Crangonidae, Family Laomedidae, Family Galatheidae, Family Parapaguridae, Family Diogenidae and Family Paguridae, having the antennal exopod not segmented; Family Pasiphaeidae, Palaemonetes zariquieyi (last stage), Infraorder Astacidea (last stage), Family Callianassidae and Family Upogebiidae having pleopod buds and the antennal exopod not segmented.

Zoea IV: pleopods absent; antennal exopod not segmented; telson almost rectangular shaped, larger on distal part; not all the pereiopods present.

Exceptions: Family Palaemonidae having all the pereiopods present; Family Hippolytidae, Family Crangonidae (last stage for Philocheras fasciatus), Family Callianassidae (last stage), Family Upogebiidae (last stage) and Family Galatheidae (last stage for Munida and Munidopsis) having all the pereiopods and pleopods present; Family Pasiphaeidae (last stage), Family Laomedidae, Family Diogenidae (last stage for Clibanarius), Family Parapaguridae and Family Paguridae (last stage) having all the pereiopods present, pleopod buds and telson triangular shaped.

Zoea V: pleopods absent; all pereiopods present; telson rectangular shaped; antennule outer flagellum segmented. Exceptions: Hippolyte (last stage) having pleopod buds; Palaemonetes varians (last stage), Family Processidae, Philocheras (last stage), Family Diogenidae (last stage) and Galathea (last stage) having pleopod buds and antennule outer flagellum not segmented; Family Laomedidae and Family Parapaguridae (last stage) having pleopod buds, antennule outer flagellum not segmented and telson triangular shaped.

Zoea VI: pleopods present as small buttons; telson pear shaped, narrower distally than proximally; antenna flagellum not segmented.

Exceptions: Palaeomon adspersus (last stage), Dichelopandalus bonnieri (last stage) and Family Crangonidae (last stage) having pleopods birramous and antenna flagellum segmented; Family Laomedidae (last stage) having antenna flagellum segmented, pleopods birramous and the telson narrower proximally than distally.

Zoea VII: antenna flagellum segmented; pleopods presented as biramous buds without setae.

Exceptions: Palaemon longirostris, P. xiphias (last stage) and Pandalina brevirostris (last stage) having the antenna flagellum segmented and twice as long as scale and the pleopod buds with setae.
Zoea VIII \& IX: these zoeal stages can be separated by the number of segments and development of the antenna flagellum, pleopods, the shape of telson and the number of rostrum spines (when is the case).

Exceptions: Brachycarpus biunguiculatus having 11 zoeal stages according to Gurney \& Lebour (1941). In this species the zoea VIII, IX, X and XI can be separated by the development of pleopods and the chela on the pereiopods 1 and 2 .

\section{REMARKS}

Although more and more new larval descriptions are being published, the characters used in the present key to distinguish between genus seems conservative. In some cases larval identification can only be taken to genus level because there are many species of the same genus occurring in the area (as in the genus Processa). In other cases, as in the genus Liocarcinus, although the complete larval development is known for all species, they show close resemblance, which render the identification a very difficult task (Clark, 1984). In a lowest identification level González-Gordillo et al. (2001) provide an annotated list of the decapod species recorded in such an area and the available references of their larval descriptions, indicating the number of larval series that remain unknown within the same area.

This research was partially supported by Acuerdo de Cooperación Bilateral entre el Consejo Superior de Investigaciones Científicas (CSIC) de España y el Instituto de Cooperação Científica e Tecnológica International (ICCTI) de Portugal (Ref: SGRI/MDH-98) and by post-doctoral fellowships to J.I.G.G. from the Ministério da Ciência e da Tecnologia (FCT), Portugal (SFRH/BPD/1596/2000).

\section{REFERENCES}

Bocquet, G., 1954. Développement larvaire d'Achaeus cranchii Leach (Décapode, Oxyrhynque). Bulletin de la Société Zoologique de France, 79, 50-56.

Bocquet, C., 1965. Stages larvaires et juvéniles de Tritodynamia atlantica (Th. Monod) (=Asthenognathus atlanticus Th Monod) et position Systématique de ce crabe. Cahiers de Biologie Marine, 6, 407-418.

Bourdillon Casanova, L., 1960. Le meroplancton du Golfe de Marseille: les larves de crustacés décapodes. Recueil des Travaux de la Station Marine d'Endoume, 30, 1-286.

Brattergard, T. \& Sankarankutty, C., 1967. On prezoea and zoea of Geryon tridens Krøyer (Crustacea, Decapoda). Sarsia, 26, 7-12.

Calafiore, N., Costanzo, G. \& Giacobbe, S., 1991. Mediterranean species of the genus Pontonia Latreille, 1829. I. Developmental stages of Pontonia pinnophylax (Otto, 1821) (Decapoda, Natantia, Pontoniinae) reared in the laboratory. Crustaceana, 60, 52-75.

Christiansen, M.E., 1973. The complete larval development of Hyas araneus (Linnaeus) and Hyas coarctatus Leach (Decapoda, Brachyura, Majidae) reared in the laboratory. Norwegian Journal of Zoology, 21, 63-89.

Christiansen, M.E. \& Anger, K., 1990. Complete larval development of Galathea intermedia Lilljeborg reared in laboratory culture (Anomura, Galatheidae). Fournal of Crustacean Biology, 10, 87-111.

Clark, P.F., 1984. A comparative study of zoeal morphology in the genus Liocarcinus (Crustacea, Brachyura, Portunidae). Zoological Journal of the Linnean Society, 82, 273-290. 
Connolly, C.J., 1925. The larval stages and megalops of Rhithropanopeus harrisi (Gould). Contributions to Canadian Biology and Fisheries, 15, 329-334.

Cuesta, J.A., González-Gordillo, J.I. \& Rodríguez, A., 1997. First zoeal stages of Grapsus adscensionis (Osbeck) and Planes minutus (Linnaeus) (Brachyura, Grapsidae) described from laboratory hatched material, with notes on larval characters of the Grapsinae. Fournal of Natural History, 31, 887-900.

Cuesta, J.A., Schubart, C.D. \& Rodríguez, A., 2000. Larval development of Brachynotus sexdentatus (Risso, 1827) (Decapoda, Brachyura) reared under laboratory conditions, with notes on larval characters of the Varunidae. Invertebrate Reproduction and Development, 38, 207-223.

dos Santos, A.M. de M., 1999. Larvas de crustáceos decápodes ao largo da costa portuguesa. $\mathrm{PhD}$ thesis, University of Lisbon, Lisbon, Portugal.

dos Santos, A. \& Lindley, J.A., 2001. Crustacea Decapoda: larvae. II. Dendobranchiata (Aristeidae, Benthesicymidae, Penaeidae, Solenoceridae, Sicyonidae, Sergestidae and Luciferidae). Fiches d'Identification du Zooplancton, 186, 1-9.

Elofsson, R., 1959. A new decapod larva referred to Calocarides coronatus (Trybom). Publications from the Biological Station, Espegrend, 26, 1-10.

Fincham, A.A. \& Williamson, D.I., 1978. Crustacea Decapoda: larvae. VI. Caridea, Families: Palaemonidae and Processidae. Fiches d'Identification du Zooplancton, 159/160, 1-8.

González-Gordillo, J.I., Cuesta, J.A. \& Rodríguez, A., 1996. Studies on the larval development of northeastern Atlantic and Mediterranean Porcellanidae (Decapoda, Anomura). IRedescription of the larval stages of Porcellana platycheles (Pennant, 1777) reared under laboratory conditions. Helgoländer Meeresuntersuchungen, 50, 517-531.

González-Gordillo, J.I. \& Rodríguez, A., 2000. First larval stage of Scyllarus posteli Forest, 1963 and Processa macrodactyla Holthuis, 1952 (Crustacea, Decapoda) hatched in the laboratory. Ophelia, 53, 91-99.

González-Gordillo, J.I. \& Rodríguez, A., 2001. The complete larval development of the spider crab, Macropodia parva (Crustacea, Decapoda, Majidae) from laboratory culture. Invertebrate Reproduction and Development, 39, 135-142.

González-Gordillo, J.I., dos Santos, A. \& Rodríguez, A., 2000. The complete larval development of Philocheras monacanthus (Holthuis, 1961) from laboratory culture, with an identification key to the European species of the genus (Decapoda, Caridea, Crangonidae). Fournal of Crustacean Biology, 20, 75-88.

González-Gordillo, J.I., dos Santos, A. \& Rodríguez, A., 2001. Checklist and annotated bibliography of decapod Crustacea larvae from the southwestern European coast (Gibraltar Strait area). Scientia Marina, 65, 275-305.

Guerao, G. \& Abelló, P., 1996. Morphology of the prezoea and first zoea of the deep-sea spider crab Anamathia rissoana (Brachyura, Majidae, Pisinae). Scientia Marina, 60, 245-251.

Guerao, G. \& Abelló, P., 1999. Morphology of the early zoeal stages of Macropipus tuberculatus (Roux, 1830) (Crustacea, Brachyura, Portunidae). Fournal of Plankton Research, 21, 1993-2008.

Guerao, G., Abelló, P. \& Cartes, J., 1998. Morphology of the megalopa and first crab instar of the shamefaced crab Calappa granulata (Crustacea, Brachyura, Calappidae). Miscellània Zoològica, 21, 37-47.

Guerao, G., Abelló, P. \& Torres, P., 1998. Morphology of the first zoea of the spider crab Macropodia linaresi (Brachyura, Majidae, Inachinae). Bolletí de la Societat d'Història Natural de les Balears, 41, 13-18.

Gurney, R., 1942. Larvae of decapod Crustacea. London: The Ray Society.
Gurney, R. \& Lebour, M.V., 1941. On the larvae of certain Crustacea Macrura, mainly from Bermuda. Fournal of the Linnean Society London, 41, 89-181.

Heegaard, P., 1963. Decapod larvae from the Gulf of Napoli hatched in captivity. Videnskabelige Meddelelser fra Dansk Naturhistorik Forening $i$ Koebenhavn, 125, 449-493.

Heldt, J.H., 1938. La réproduction chez les Crustacés Décapodes de la famille des Pénéides. Annales l'Institut Océanographique, 18, 31-206.

Ingle, R.W., 1979. The larval development of the spider crab Rochinia carpenteri (Thomson) (Oxyrhyncha, Majidae) with a review of majid subfamily larval features. Bulletin of the British Museum, Natural History, Zoology, 37, 47-66.

Ingle, R.W., 1981. The larval and postlarval development of the edible crab Cancer pagurus Linnaeus (Decapoda, Brachyura). Bulletin of the British Museum, Natural History, Zoology, 40, 211-236.

Ingle, R.W., 1983. A comparative study of the larval development of Monodaeus couchi (Couch), Xantho incisus (Leach) and Pilumnus hirtellus (Linnaeus) (Crustacea, Brachyura, Xanthidae). Journal of Natural History, 17, 951-978.

Ingle, R.W., 1984. The larval and post-larval development of the thumb-nail crab, Thia scutellata (Fabricius) (Decapoda, Brachyura). Bulletin of the British Museum, Natural History, Zoology, 47, 53-64.

Ingle, R.W., 1985. Larval development of the red swimming crab, Bathynectes longipes (Risso, 1816) (Crustacea, Decapoda, Portunidae). Bulletin of the British Museum, Natural History, Zoology, 49, 239-255.

Ingle, R.W., 1987. The first zoea of three Pachygrapsus species and of Cataleptodius floridanus (Gibbes) from Bermuda and Mediterranean (Crustacea, Decapoda, Brachyura). Bulletin of the British Museum, Natural History, Zoology, 52, 31-41.

Ingle, R.W., 1992. Larval stages of northeastern Atlantic crabs. An illustrated key. London: Chapman \& Hall.

Kemp, S.W., 1910. The Decapoda Natantia of the coast of Ireland. Fisheries, Ireland, Scientific Investigations, 1908, 1-190.

Lebour, M.V., 1930. The larvae of the Plymouth Galatheidae, I. Munida banffica, Galathea strigosa and Galathea dispersa. Fournal of the Marine Biological Association of the United Kingdom, 17, 175-181.

Lebour, M.V., 1932. The larval stages of the Plymouth Caridea. III: the larval stages of Spirontocaris cranchii (Leach). Proceedings of the Zoological Society of London, 1932, 131-137.

Lebour, M.V., 1940. The larvae of the Pandalidae. Fournal of the Marine Biological Association of the United Kingdom, 24, 239-252.

Lumare, F. \& Gozzo, S., 1972. Sviluppo larvale del crostaceo Xanthidae Eriphia verrucosa (Förskal, 1775) in condizioni di laboratorio. Bolletino di Pesca Piscicoltura e Idrobiologia, 27, 185-209.

Martin, J.W. \& Davis, G.E., 2001. An updated classification of the Recent Crustacea. Natural History Museum of Los Angeles County, Science Series, no. 39, 124 pp.

Paula, J., 1985. The first zoeal stages of Polybius henslowi Leach, Maja squinado (Herbst), Pachygrapsus marmoratus (Fabricius), and Uca tangeri (Eydoux) (Crustacea, Decapoda, Brachyura). Arquivos do Museu Bocage, 2, 137-147.

Paula, J., 1987. Planktonic stages of brachyuran crabs from the south-western Iberian coast (Crustacea, Decapoda, Brachyura). Journal of Natural History, 21, 717-756.

Paula, J., 1988. The larval development of the spider crab Maja goltziana d'Oliveira, 1888 (Crustacea, Decapoda, Majidae) reared in the laboratory. Fournal of Natural History, 22, 1697-1708.

Paula, J., 1993. Ecologia da fase larvar e recrutamento de Crustáceos Decápodos no Estuário do Rio Mira. PhD thesis, University of Lisbon, Lisbon, Portugal.

Paula, J., 1996. A key and bibliography for the identification of zoeal stages of brachyuran crabs (Crustacea, Decapoda, Brachyura) from the Atlantic coast of Europe. Fournal of Plankton Research, 18, 17-27. 
Paula, J. \& Cartaxana, A., 1991. Complete larval development of the spider crab Stenorhynchus lanceolatus (Brullé, 1837) (Decapoda, Brachyura, Majidae) reared in the laboratory. Crustaceana, 60, 113-122.

Paula, J. \& Hartnoll, R.G., 1989. The larval and post-larval development of Percnon gibbesi (Crustacea, Brachyura, Grapsidae) and the identity of the larval genus Pluteocaris. Fournal of Natural History, 21, 17-37.

Pessani, D., Burri, R. \& Salton, L., 1998. A key for the identification of the known larval stages of the Mediterranean Brachyura. Invertebrate Reproduction and Development, 33, 191-199.

Pike, R.B. \& Williamson, D.I., 1958. Crustacea Decapoda: larvae. XI. Paguridea, Coenobitidae, Dromiidea, and Homolidea. Fiches d'Identification du Zooplancton, 81, 1-9.

Pike, R.B. \& Williamson, D.I., 1960. Larvae of decapod Crustacea of the families Diogenidae and Paguridae from the Bay of Naples. Publicazioni della Stazione Zoologica di Nàpoli, 31, 493-552.

Pike, R.B. \& Williamson, D.I., 1972. Crustacea Decapoda: larvae. X. Galatheidea. Fiches d'Identification du Zooplancton, 139, $1-5$.

Rice, A.L., 1980. The first zoeal stage of Ebalia nux Milne Edwards, 1883, with a discussion of the zoeal characters of the Leucosiidae (Crustacea, Decapoda, Brachyura). Fournal of Natural History, 14, 331-337.

Rice, A.L. \& Ingle, R.W., 1975. The larval development of Carcinus maenas (Linnaeus) and Carcinus mediterraneus Czerniavsky (Crustacea, Brachyura, Portunidae) reared in the laboratory. Bulletin of the British Museum, Natural History, Zoology, 28, 101-119.

Rice, A.L. \& Von Levetzon, K.G., 1967. Larvae of Homola (Crustacea, Dromiacea) from South Africa. Journal of Natural History, 1, 435-453.

Rice, A.L. \& Williamson, D.I., 1977. Planktonic stages of Crustacea Malacostraca from the Atlantic Sea Mounts. Meteor Forschungsergehnisse, 26, 28-64.

Rodríguez, A., González-Gordillo, J.I. \& Guesta, J.A., 1992. Larval stages of Brachynotus atlanticus Forest, 1957 (Crustacea, Decapoda, Grapsidae) reared under laboratory conditions. Journal of Plankton Research, 14, 867-883.

Rodríguez, A. \& Martin, J.W., 1997. Larval development of the crab Xantho poressa (Decapoda, Xanthidae) reared in the laboratory. Fournal of Crustacean Biology, 17, 98-110.

Rodríguez, A. \& Paula, J., 1993. Larval and postlarval development of the mud crab Panopeus africanus Milne Edwards (Decapoda, Xanthidae) reared in the laboratory. Fournal of Crustacean Biology, 13, 296-308.
Saint-Laurent Dechancé, M., 1964. Dévelopment et position systématique du genre Parapagurus Smith (Crustacea, Decapoda, Paguridea). I. Description des states larvaires. Bulletin de l'Institut Océanographique Monaco, 64, 1-26.

Salman, S.D., 1982. Observations on the larvae of north European crabs of the genus Ebalia (Brachyura, Leucosiidae). Crustaceana, 42, 256-269.

Samuelsen, T.J., 1972. Larvae of Pagurus variabilis Milne-Edwards and Bouvier (Decapoda, Anomura) reared in the laboratory. Sarsia, 48, 2-11.

Samuelsen, T.J., 1976. The first zoea of Paromola cuvieri (Risso) (Decapoda, Homolidae). Sarsia, 62, 5-8.

Santucci, R., 1925. Contributo allo studio dello sviluppo postembrionale degli Scyllaridea del Mediterraneo II: Scyllarus arctus. III: Scyllarides latus. Memoria Reale Comitato Talassografico Italiano, 71, 1-16.

Sars, G.O., 1890. Bidrag til kundskaben om Decapodernes Forvandlinger. III: Crangonidae. Archiv for Mathematik og Naturvidenskab, 14, 132-195.

Sars, G.O., 1900. Account of the postembryonal development of Pandalus borealis Krøyer with remarks on the development of other Pandali and description of the adult Pandalus borealis. Reports on Norwegian Fishery and Marine Investigations, 1, 1-45.

Sars, G.O., 1911. Account of the post-embryonal development of Hippolyte varians Leach. Archiv for Mathematik og Naturvidenskab, $32,1-25$.

Schubart, C.D., González-Gordillo, J.I., Reyns, N.B., Liu, H.G. \& Cuesta, J.A., 2001. Are Atlantic and Indo-Pacific populations of the rafting crab, Plagusia depressa, distinct? New evidence from larval morphology and mtDNA. The Raffles Bulletin of Zoology, 49, 301-310.

Selbie, C.M., 1914. The Decapoda Reptantia of the coast of Ireland. I. Palinura, Astacura and Anomura (except Paguridea). Fisheries, Ireland, Scientific Investigations, 1, 1-116.

Seridji, R., 1988. Some planktonic larval stages of Albunea carabus (L., 1758) (Crustacea, Decapoda, Anomura). Fournal of Natural History, 22, 1293-1300.

Williamson, D.I., 1957. Crustacea, Decapoda: larvae. I. General. Fiches d'Identification du Zooplancton, 67, 1-7.

Williamson, D.I., 1960. Crustacea Decapoda: larvae. VII. Caridea, Family Crangonidae; Stenopodidea. Fiches d'Identification du Zooplancton, 90, 1-5.

Williamson, D.I., 1960a. Larval stages of Pasiphaea sivado and some other Pasiphaeidae (Decapoda). Crustaceana, 1, 331-341.

Williamson, D.I., 1969. Names of larvae in the Decapoda and Euphausiacea. Crustaceana, 16, 210-213.

Submitted 7 August 2002. Accepted 19 August 2003. 